Scholarship Repository

University of Minnesota Law School

Articles

Faculty Scholarship

2008

\title{
The Malign Effects of Drug and Crime Control Policies on Black Americans
}

Michael Tonry

University of Minnesota Law School, tonry001@umn.edu

Matthew Melewski

Follow this and additional works at: https://scholarship.law.umn.edu/faculty_articles

Part of the Law Commons

\section{Recommended Citation}

Michael Tonry and Matthew Melewski, The Malign Effects of Drug and Crime Control Policies on Black Americans, 37 CRIME \& JUST. 1 (2008), available at https://scholarship.law.umn.edu/faculty_articles/499.

This Article is brought to you for free and open access by the University of Minnesota Law School. It has been accepted for inclusion in the Faculty Scholarship collection by an authorized administrator of the Scholarship Repository. For more information, please contact lenzx009@umn.edu. 


\section{Michael Tonry and Matthew Melewski}

\section{The Malign Effects of Drug and Crime Control Policies on Black Americans}

\section{ABSTRACT}

The disproportionate presence of blacks in American prisons, jails, and Death Rows, and the principal reasons for it-higher rates of commission of violent crimes and racially disparate effects of drug policies and sentencing laws governing violent and drug crimes-are well known. Since the late $1980 \mathrm{~s}$, black involvement in violent crime has declined substantially, but racial disproportions have not. Blacks are six to seven times more likely than whites to be in prison. Nearly a third of young black men are under criminal justice system control. A third of black boys born in 2001 are predicted to spend some time in prison. The simplest explanation for these patterns is that drug and sentencing policies that contribute to disparities have not been significantly changed in decades. The question then is, why not? The answer is that the white majority does not empathize with poor black people who wind up in prison. That in turn is because recent punishment policies have replaced the urban ghetto, Jim Crow laws, and slavery as a mechanism for maintaining white dominance over blacks in the United States.

Seen from outside the United States, and, we expect, as it will be seen by future generations of Americans, four aspects of contemporary crime control policies stand out: the world's highest imprisonment rate, the Western world's only use of capital punishment, the Western world's most severe punishments short of death, and the effects of those policies on black Americans. Gross racial disparities in impris-

Michael Tonry is Sonosky Professor of Law and Public Policy, University of Minnesota Law School, and senior fellow, Netherlands Institute for the Study of Crime and Law Enforcement. Matthew Melewski is a 2008 graduate of the University of Minnesota Law School. They are grateful to Alfred Blumstein, Richard Frase, Marc Mauer, Myron Orfield, and Kevin Reitz for helpful comments on earlier drafts. 
onment and entanglement in the criminal justice system result partly from racial differences in offending, but preponderantly from adoption and continuation of drug and crime control policies that affect black Americans much more severely than whites. Much of the harm being done to disadvantaged black Americans and their loved ones in the name of crime control was, and is, avoidable.

The litany of ways crime control policies disproportionately affect black Americans by now is so familiar as to be unsurprising. Blacks constituted 12.8 percent of the general population in 2005 but nearly half of prison inmates and 42 percent of Death Row residents. Imprisonment rates for black men were nearly seven times higher than for white men. About a third of young black men aged 20-29 were in prison or jail or on probation or parole on an average day in 2005. The Bureau of Justice Statistics (BJS) estimated in 2003 that 32 percent of black men born in 2001 will spend some part of their lives in a state or federal prison. That is a substantial underestimate of the likelihood that black men will spend time behind bars; it does not take account of jail confinement, which is much more common than time in prison (Bonczar 2003; BJS 2007, tables 6.33.2005, 6.17.2006, 6.80.2007).

What is surprising is not that these things are true, but that they are well known, have long been well known, and have changed little in recent decades. Few people except academics and liberal law reformers-seemingly almost no policy makers-much notice or care. The racial disparities caused by the federal 100-to-one law that punishes crack cocaine offenses much more severely than powder cocaine offenses were foreseeable when the law was passed (Tonry 1995, pp. 4-6) and were irrefutably documented long ago (McDonald and Carlson 1993). The law remains in effect, successively endorsed by the Reagan, Bush I, Clinton, and Bush II administrations. ${ }^{1}$

To take another example, the Congressional Black Caucus, during consideration of federal crime legislation in 1994, fought hard for a Racial Justice Act that would allow statistics on racial disparities in

\footnotetext{
${ }^{1}$ The U.S. Sentencing Commission repeatedly urged the Congress to repeal or diminish the crack/powder sentencing differential (e.g., U.S. Sentencing Commission 1995). Attorney General Janet Reno initially endorsed the commission's 1995 proposal to eliminate the 100-to-one differential, and, backtracking, she and "drug czar" General Barry McCaffrey later called for it to be reduced to 10-to-one, but to no avail (Tonry 2004, chap. 1). In 2007, the commission proposed amendment of guideline provisions that made federal sentencing even tougher than the mandatory minimum law required. The Congress through inaction allowed the amendments to take effect. The statute itself, which does the main damage, continued in effect early in 2008 , unchanged.
} 
capital punishment to be introduced in death penalty cases. David Baldus and his colleagues, using Georgia data on 2,000 cases from the 1970 s, had convincingly shown that the racial characteristics of murder defendants and victims were powerfully associated with whether capital punishment is imposed (Baldus, Woodworth, and Pulaski 1990). Twenty-two percent of black killers of white victims were sentenced to death compared with 3 percent of white killers of blacks (prosecutors sought death in 70 percent of black-on-white killings and 19 percent of white-on-black). The U.S. Supreme Court in McCleskey v. Kemp (481 U.S. 279 [1987]) decided that such evidence was irrelevant in deciding claims about racial discrimination. Even though the court "assumed the study is statistically valid" (n. 8), it ruled that a defendant alleging discrimination had to prove that the prosecutor in that particular case had acted in a biased way. This is almost impossible to do; bigoted officials seldom admit to acting in bigoted ways.

For a time, it appeared likely that President Clinton would support the caucus. In the end, he did not. Instead he signed the Violent Crime Control and Law Enforcement Act of 1994, which created more than 50 new federal capital offenses; the caucus's proposed provision had been dropped (Gest 2001, pp. 230-35). For a few years in the 1990s, the caucus continued to support federal legislation attempting to reduce racial disparities in death penalty cases, but the issue gradually died down. The proportion of blacks on Death Row was about the same in 2007 as it had been in 1994.

A third example: Daniel Patrick Moynihan in 1965 urged a controversial welfare policy of benign neglect toward poor black Americans, arguing that they needed mostly to be let alone to get on with their lives. American crime control policies in the early twenty-first century do the opposite of that. They diminish the life chances of black men (Western 2006; Provine 2007) and undermine the social fabric of many poor black communities (Clear 2007).

Since at least 1980, American crime control policies have undermined achievement of full unbiased participation of black Americans in the nation's social, economic, and political life. Modern wars on crime and drugs, which date from the early 1970s, shortly after the first serious federal antidiscrimination laws were enacted, could not more effectively have kept black Americans "in their place" had they been designed with that aim in mind.

The following list of social, vocational, educational, and economic 
differences between blacks and whites is drawn from the 2007 Statistical Abstract of the United States:

- 33.3 percent of black children lived in households below the poverty line in 2004, compared with 14.2 percent of white children;

- the mortality rate for black infants in 2003 was 14 per 1,000 live births, compared with 5.7 per 1,000 for whites;

- per capita income for black Americans was \$16,035 in 2004, compared with $\$ 25,203$ for whites;

- 10 percent of adult blacks were unemployed and 35.8 percent were not in the labor force in 2005 , compared with 4.4 and 33.7 percent of whites;

- 17.6 percent of blacks 25 and older had college degrees in 2005, compared with 28 percent of whites; and

- 48.1 percent of blacks owned their own homes in 2005, compared with 72.7 percent of whites (U.S. Department of Commerce 2006, tables $107,214,575,685,693,954)$.

Those differences have been at least exacerbated by, and are probably substantially attributable to, the nearly seven-to-one racial difference in imprisonment rates that has been typical for the past quarter century, the staggering difference in black and white men's lifetime chances of going to prison, and the entanglement of a large minority of young black men in their $20 \mathrm{~s}$ in the justice system at a time of life when other young men are building careers and conventional lives (Western 2006). Accumulating bodies of research show that going to prison reduces employment prospects and average and lifetime earnings (Fagan and Freeman 1999; Raphael, Holzer, and Stoll 2006) and reduces the later well-being of prisoners' children (Murray and Farrington, in this volume). A different literature shows that disadvantaged communities are damaged, not helped, when large numbers of their residents are sent to prison. Low levels of imprisonment at least arguably may prevent crime through deterrence, incapacitation, and removal of antisocial role models; high levels cause crime rates to increase and neighborhoods to deteriorate (Clear 2007; in this volume).

If incarceration rates for jail and prison together had remained at 1970 levels (around 130 per 100,000) or at 1980 levels (around 200), American crime control policies would have bitten much less deeply into black American communities. American crime rates reached their all-time high in 1981 , so the 1980 comparison is probably the better 
one. Less than a third of black Americans in prison in 2008 would be there had 1980 rates continued. Many fewer black men would have suffered the pains of imprisonment, resulting stigma, and reduced employment prospects. There would have been many fewer broken black families, fewer negative role models for black boys, and more marriageable black men. There would have been less deterioration in poor black communities because tipping points would not have been reached. At a time when civil rights and welfare policies aimed at improving opportunities and living standards for black Americans, drug and crime policies worsened them.

Scholars have long paid attention to interactions among race, crime, and criminal justice (e.g., Du Bois [1899] 1988; Myrdal 1944). The modern literature dates from Alfred Blumstein's at the time courageous 1982 article showing that a principal reason why so many more blacks than whites were in prison was that they were much more often arrested for the kinds of crimes that typically resulted in prison sentences. ${ }^{2}$ The more serious the crime, the more fully offending patterns appeared to explain racial disparities in imprisonment. ${ }^{3}$ That conclusion was tested in lots of ways-for example, by comparing racial patterns in victims' identifications of assailants with racial patterns in arrests and by comparing arrests and victims' reports to prison admissions-but held up at least through the mid-1990s (Langan 1985; Tonry 1995, chaps. 2, 3).

Substantial literatures have continued to accumulate on racial pat-

2 "Courageous" because at the time racial issues were so sensitive that few scholars, black or white, could write about racial differences in offending without being accused of racism, blaming the victims of racial discrimination, or perpetuating racially harmful stereotypes. William Julius Wilson, a black American who is among the most distinguished and influential sociologists of his generation, wrote a landmark book, The Declining Significance of Race, in which he argued that poor blacks' main problem was not racism and discrimination per se but the deindustrialization of the American economy and the loss of semi- and unskilled industrial jobs in American cities (Wilson 1978). In the preface to his next major book, The Truly Disadvantaged, he observed that critics "either labeled me a neoconservative or directly or indirectly tried to associate The Declining Significance of Race with the neoconservative movement. . . . I am a social democrat and probably to the left politically of the overwhelming majority of these critics" (1987, p. viii).

${ }^{3}$ Conversely, the less serious the offense, the less offending differences appeared to explain disparities. For drug offenses, arrests are simply artifacts of police tactics and cannot sensibly be used as behavioral measures. Blumstein's article was controversial at the time but in retrospect is easily consonant with research on sentencing outcomes, which generally shows few racial differences in the probability of imprisonment for the most serious offenses. The space for bias, unconscious stereotyping and attribution, and other nonoffense factors to affect outcomes increases as prison sentences become less likely (Spohn 2000). 
terns in arrests (with particular emphasis on profiling) and on racial differences in sentencing. The arrest literature shows that blacks in most places are more likely than whites to be stopped by the police, regardless of whether rates for pedestrian stops are calculated according to neighborhood population or according to transient population, and for traffic stops regardless of whether rates are calculated according to general population or to drivers of automobiles vulnerable to being stopped. Once stopped, blacks (and Hispanics) are more likely than whites to be searched, to be arrested, and to have force used against them. Percentages of stops resulting in seizures of contraband, however, tend to be lower for blacks than for whites, suggesting that police are likelier to stop blacks for less valid, often pretextual, reasons (e.g., Engel and Calnon 2004, pp. 77-81). ${ }^{4}$

The sentencing literature documents relatively small racial differences. Black defendants, all else being equal, are slightly more likely than whites to be sentenced to confinement but, among those incarcerated, not to receive longer sentences (Spohn 2000, 2002). Blacks are less likely than whites to be diverted to nonincarcerative punishments and more likely in guidelines states to receive sentences at the tops rather than the bottoms of sentencing guidelines ranges (Tonry 1996, chap. 2). Individual studies present divergent findings, often showing disparities by race and ethnicity for men but not for women (or to different extents), for Hispanics but not for blacks, and for young offenders but not for older ones (or in each case vice versa) (e.g., Walker, Spohn, and DeLone 2006; Harrington and Spohn 2007, pp. 40-45).

In this essay we examine the empirical issues that Michael canvassed nearly 15 years ago in Malign Neglect (Tonry 1995) to see to what extent black/white differences in victimization, offending, drug use, arrest, sentencing, imprisonment, and capital punishment have changed. They have changed very little.

Section I surveys case processing data on arrest through capital punishment and discusses recent survey data on racial differences in drug use and trafficking. Although conscious bias and stereotyping probably explain some portion of racial disparities, and unconscious stereotyping surely does, the principal drivers of disparities in imprisonment continue to be racial differences in commission of "imprisonable" offenses

\footnotetext{
4 Table 1 in Engel and Calnon (2004) summarizes data from 16 studies, of which 10 report higher hit rates for whites. Engel and Calnon's own study, based on National Crime Victimization Survey (NCVS) data, finds substantially higher white hit rates.
} 
and the foreseeable disparate effects on blacks and whites of police tactics in the war on drugs and sentencing policies for violent and drug offenses.

Section II explains the patterns the preceding sections document. Because much racial disparity is attributable to the effects of policies that could have been foreseen to affect black offenders disproportionately severely and are now widely recognized to have that effect, the fundamental questions are how that could have happened and why it has been allowed to continue to happen. The answer is that political and ideological exigencies of the last quarter century have conduced to the adoption of crime control policies of unprecedented severity, the primary burdens of which have been borne by disadvantaged blacks (and, increasingly, Hispanics). The history of American race relations has produced political and social sensibilities that made white majorities comparatively insensitive to the suffering of disadvantaged blacks.

Section III proposes ways that avoidable disparities can be reduced.

\section{Racial Differences in Criminal Justice System Case Processing}

Here is what was known in the mid-1990s about racial disparities in the criminal justice system (Tonry 1995, chap. 2). For a century before the 1960s black people had been more likely to be held in prison than whites. Racial disparities began to rise in the 1960s and then shot up to all-time highs in the $1980 \mathrm{~s}$ : blacks by then were half of American prisoners, though only 12 percent of the U.S. population, and had an imprisonment rate seven times higher than the white rate. Part of the reason for this was that blacks were sometimes treated more harshly than whites for reasons of bias or unconscious stereotyping. A larger part of the explanation, however, was that blacks were more likely than whites to be arrested for the "imprisonable" offenses of robbery, rape, aggravated assault, and homicide. Victimization data on victims' descriptions of assailants and police data on victim and offender characteristics in homicide cases suggested that the racial offending patterns shown in arrest data for serious crimes were not far off from reality. Critically, however, there had been no significant shifts in racial patterns in arrests for a quarter century, and involvement in serious violent crime could not explain why black imprisonment rates had risen so rapidly since the late 1960 s. A principal driver of the increase was 
imprisonment for drug crimes (Blumstein and Beck 1999), and policy makers knew or should have known that the enemy foot soldiers in the war on drugs would be young, disadvantaged, inner-city members of minority groups (Tonry 1995).

Little in that paragraph would need to be changed to describe conditions in 2007 rather than in 1993-94. Racial differences in commission of serious violent crimes continue to be an important contributor to imprisonment disparities, but the absolute overrepresentation of blacks among arrestees has declined significantly. Imprisonment rates, however, were much higher in 2007 than in 1993, and with their increase the lifetime probability of imprisonment for black men and the percentage of young black men under justice system control both increased substantially. The black fractions of the prison, jail, and Death Row populations have changed little. Nor has the difference in black imprisonment rates compared to white rates changed significantly. Policies authorizing or requiring harsh punishments for drug offenses continue to be one major contributor to racial disparities. Another is staggering increases in severity of sentences for violent crime: if 40-50 percent of people arrested for violent crimes are black, then black Americans are foreseeably bearing the burdens of increased harshness.

\section{A. Incarceration Rates}

Figure 1 shows black and white percentages of state and federal prisoners from 1950 to 2006. Blacks were about a third of prisoners in 1960 and under 40 percent in 1970 . The black percentage rose continuously to the mid-40s around 1980, rising slowly thereafter until the early 1990s and plateauing at about 50. For most years between 1991 and 2002, in absolute numbers there were more black than white prisoners. The black percentage has since declined slightly.

Calculation of trend data has been complicated by a BJS decision beginning in the late 1990s to report separate figures for blacks, whites, and Hispanics. In earlier years, Hispanics were included within racial categories and sometimes also reported separately. The BJS change had the effect of reducing "black" imprisonment rates. In our view, skin color and "racial" identity have been more salient social characteristics in recent decades in the United States than the Hispanic/non-Hispanic difference has been. Insofar as racial bias, stereotypes, and attributions have influenced officials' decisions, appearance is much more likely than a Hispanic surname or ancestry to have influenced decisions. Ac- 


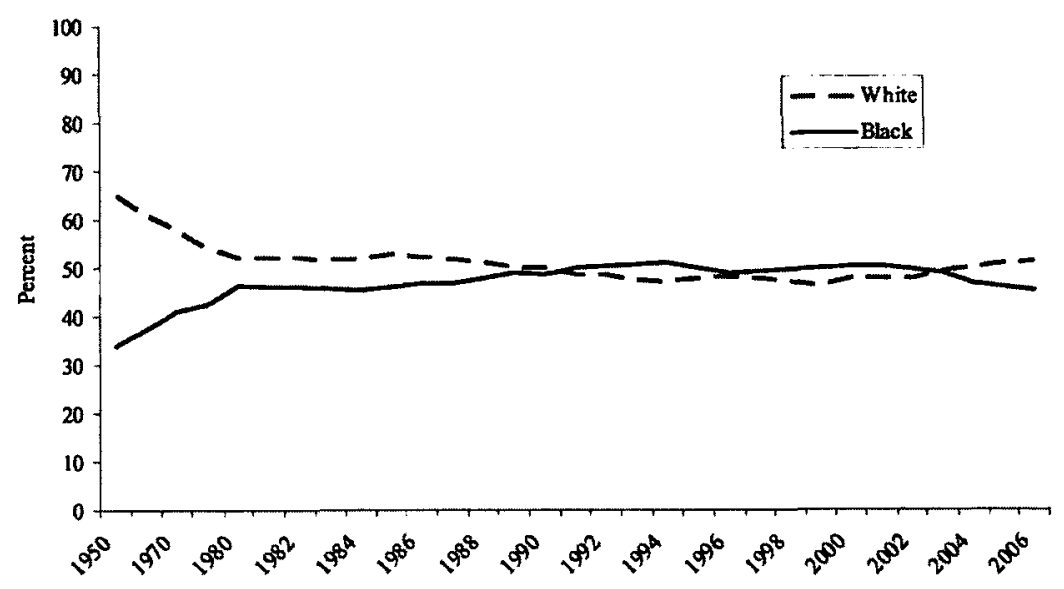

FIG. 1.-Percentage of state and federal prisoners, by race, 1950-2006. Sources: For 1950-80: Cahalan (1986); for 1980-2006: BJS, "Prisoners," various years. Until the late 1990 s, race was broken down into three categories for all statistics: white, black, and other. In recent years, BJS added Hispanic as a racial category to various statistics, thus complicating linear representations of the data. In 1999, BIS added Hispanic as a racial category to combined state and federal prison statistics (skipping 1998 in the process). BJS also revised some data in later years, occasionally creating three different data points for a single year. In 2004, BJS added the category of "two or more races," further complicating the data. We have adopted the approach taken in Tonry (2005). The Hispanic category has been removed and redistributed for every year since 1999. This redistribution was made by examining the years 1990 and 1995, for which BJS has supplied data both with and without a separate Hispanic category. Approximately one-fourth of Hispanics were formerly counted as black in those years, and three-quarters were counted as white. For all years, the most recent published BJS data were used, except for 1990 and 1995. For those years, the older data without the Hispanic separation were used. The category of "two or more races" has been redistributed evenly between blacks and whites.

cordingly, in figure 1 (and other figures) we adjusted BJS prison population data to take account of the estimated black/white fractions among Hispanics. ${ }^{5}$

The jail story is much the same, as figure 2 shows. About a third of

${ }^{5}$ The method for redistributing Hispanics was determined by examining 1990 and 1995 data in which the BJS reported black/white figures including Hispanics and also reported Hispanics separately. For 1995, e.g., 17.6 percent of prisoners were classified as Hispanic. Excluding Hispanics, 45.7 percent of prisoners were black and 33.5 percent were white. Including Hispanics, 49.9 percent were black and 47.7 percent were white. Simple math shows that approximately one-fourth of Hispanics were counted as black and three-fourths as white (Tonry 2005, p. 1255, n. 99). 


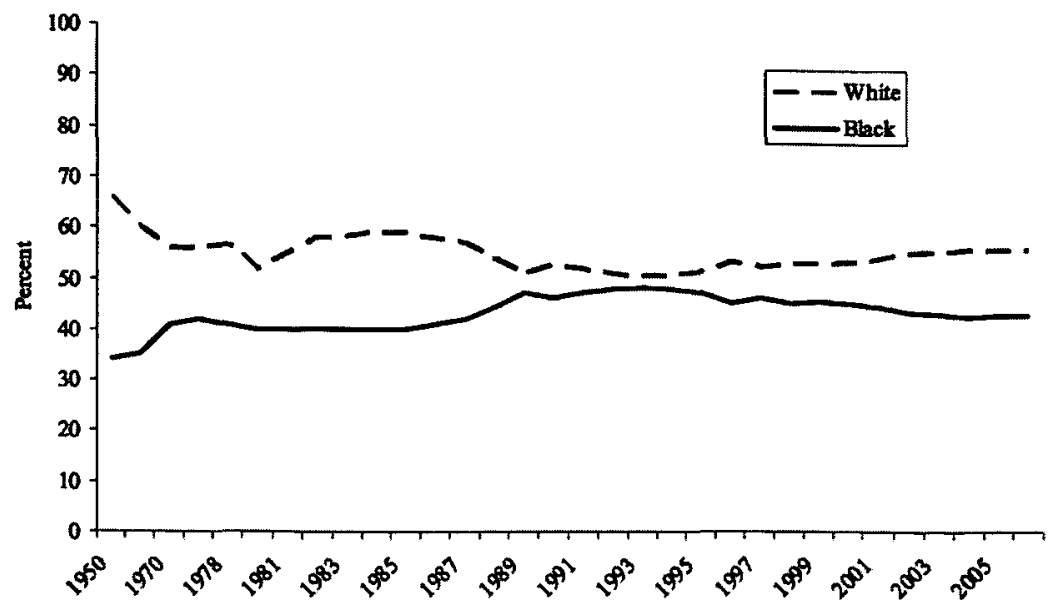

FIG. 2.-Percentage of local jail inmates, by race, 1950-2006. Sources: For 1950-83: Cahalan (1986); BJS (1984, 1990); for 1983-89: BJS, "Jail Inmates," various years; for 1990-95: Gilliard and Beck (1996); for 1996-2006: BJS, "Prison and Jail Inmates at Midyear," various years. BJS began using a separate Hispanics category much earlier in reporting jail data than in reporting prisoner data. For every year starting in 1990 the Hispanic category has been removed and redistributed, estimating that one-fourth of Hispanics were previously counted as black and three-quarters were counted as white.

jail inmates were black in 1950 and about 40 percent in 1970, a level around which the black percentage oscillated until the late 1980s. For a decade after that, coinciding with the most aggressive years of the war on drugs, blacks were $45-48$ percent of inmates, after which the percentage declined somewhat. BJS data for the years 1990-2006 have been adjusted to distribute Hispanics between blacks and whites.

Because the preceding two figures are expressed in black/white percentages, they do not reflect the true magnitude of racial differences in imprisonment rates. It would be natural for someone new to the subject to compare the black percentage of the general population (12-13 percent) to the black percentages of the combined jail and prison populations (48-50 percent) and conclude that blacks are four times more likely to be confined than should be expected. The true difference in recent years has typically been about seven times. The reason is that whites are underrepresented in prison compared with their presence in the population and blacks are overrepresented. In 2006, for example, the total imprisonment rate for black men for jail 


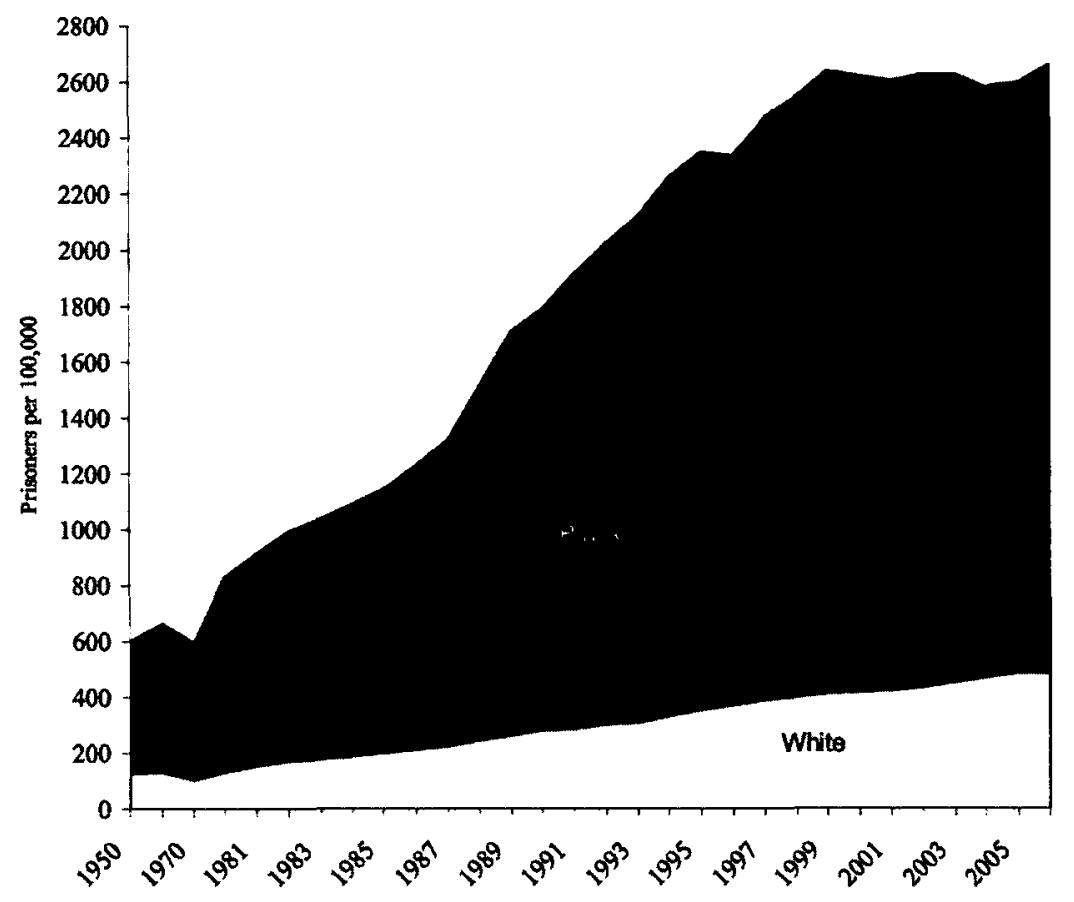

FIG. 3.-Incarceration in state and federal prisons and local jails per 100,000, by race, 1950-2006. Sources: BJS (1984, 1990; "Jail Inmates," various years; "Prisoners," various years; "Prison and Jail Inmates at Midyear," various years); Cahalan (1986); Gilliard and Beck (1996). The BJS occasionally publishes the number of prisoners in state and federal prisons and local jails, by race, as a ratio of the races' respective general populations (what we might call the total imprisonment rate). The publications are sporadic and interspersed with the ratio only for state prisons, only for state and federal prisons, only for local jails, or (most commonly) only for males. This graph is based on data used in figs. 1 and 2, then compared with population statistics provided by the Census Bureau.

and prison combined was 4,789 per 100,000 residents and the white rate was 737 per 100,000 (the corresponding rates for black and white women were 358 and 94) (Sabol, Minton, and Harrison 2007, table 14). ${ }^{6}$

Figure 3 shows aggregate black/white incarceration rates for jails and federal and state prisons from 1950 to 2006 . Black rates dwarf those of whites. The increase in the black rate between 1980 and $2006(1,834$

${ }^{6}$ These numbers understate the rates since, per current BJS practice, Hispanic blacks and whites are excluded. 


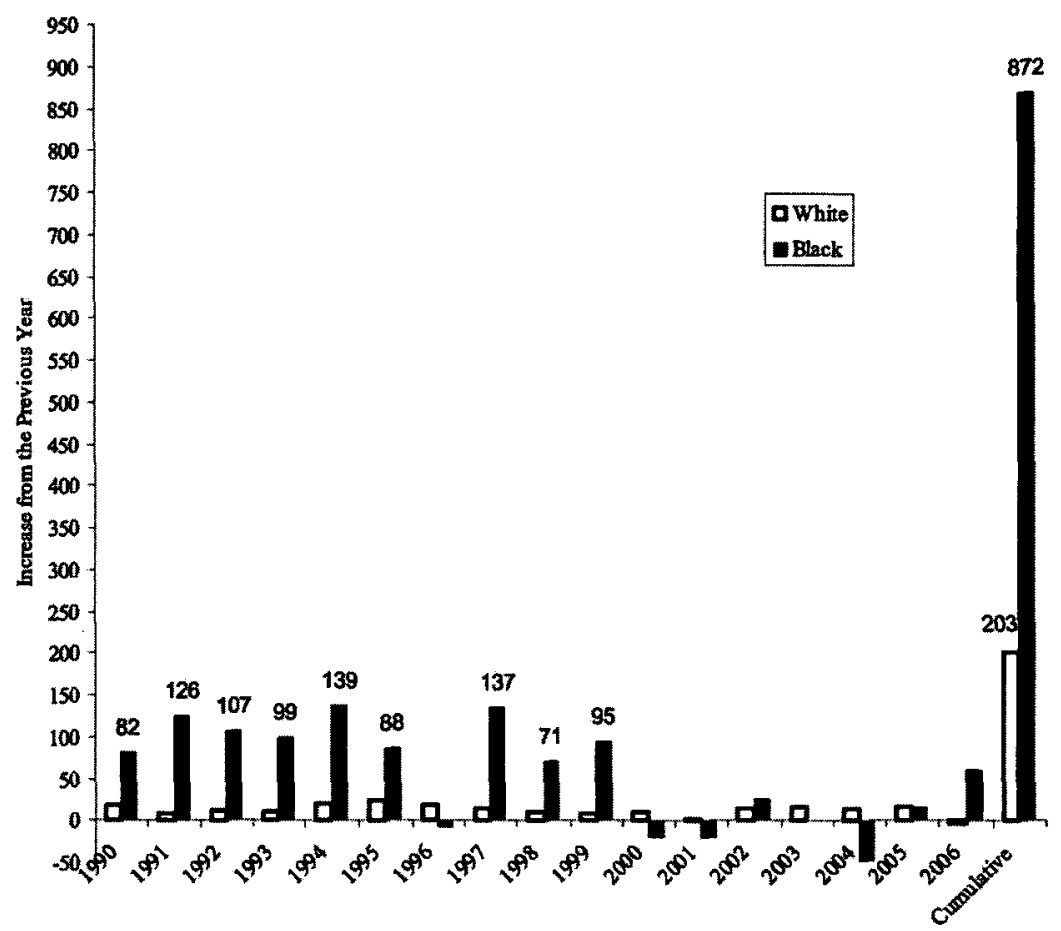

FIG. 4.-Increases in the total imprisonment rate per 100,000, by race, 1990-2006. Sources: Same as fig. 3.

per 100,000$)$ was 3.8 times the total white rate $(483$ per 100,000$)$ in 2006. The magnitude of racial differences in combined incarceration rates can be illustrated in another way. By 2006, the white rate (483), after 33 years of increases beginning in 1973, failed to reach the black rate in 1950 (598).

The racial difference in aggregate imprisonment rates is huge, as figure 3 shows. The extent to which increased imprisonment over recent decades has destabilized America's black population can be shown in another way. The nearly seven-to-one difference in imprisonment rates continued nearly unchanged for a quarter century. That means that the incremental increase for blacks each year, on average, has been seven times higher than the increase for whites. Figure 4 shows this. It depicts year-to-year increases in total imprisonment rates for blacks and whites from 1990 to 2006 and, following 2006, the cumulative 


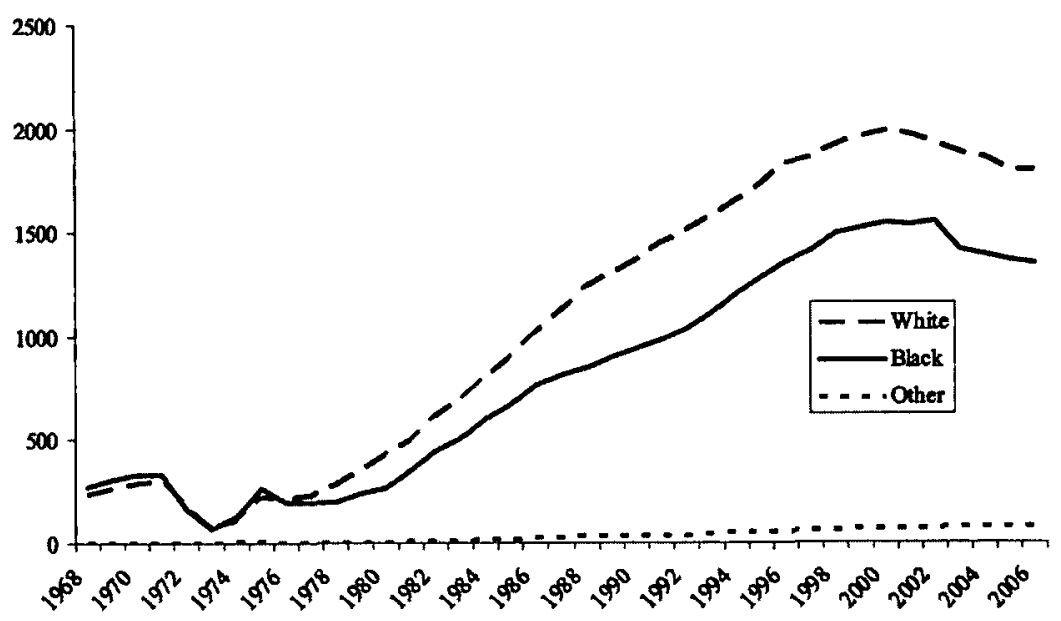

FIG. 5.-Prisoners under sentence of death, by race, 1968-2006. Source: Snell (2007)

increases. In 9 of the 17 years shown, the increase in black imprisonment rates exceeded 70 per 100,000 . In four of those years, the increase exceeded 100 per 100,000. Those 1-year increases exceed the total imprisonment rates of Canada and most European countries. ${ }^{7}$ Over 17 years, the black rate increased by 872 per 100,000 and the white rate by 203 , a difference approaching 500 percent.

Racial disparities on Death Row parallel those for imprisonment generally. Figure 5 shows absolute numbers of blacks and whites on Death Row. The black fraction has not changed significantly for 25 years, despite a steep decline in homicide rates and despite, as we show below, a significant decline in the percentages of blacks arrested for homicide.

The disproportionate presence of blacks in American prisons and jails has not changed substantially since 1980 . The important question is why.

${ }^{7}$ In 2005, the imprisonment rates for the Scandinavian countries ranged between 70 and 85 per 100,000 population. The rates for France, Germany, Belgium, and Austria were under 100 per 100,000 . The Canadian rate was just above 100 per 100,000 (Walmsley 2007). 


\section{B. Racial Differences in Criminality as Explanations for Imprisonment Rates}

Twenty-five years ago possible explanations for why the prison population was nearly half black were contentious and hotly disputed. Suspicions that criminal justice officials were racially biased and labored under the influence of racial stereotypes detrimental to blacks were widespread (e.g., American Friends Service Committee 1971). Within a decade, however, a consensus view emerged that, though bias and stereotyping existed, they were not the primary drivers of racial disparities in imprisonment. For serious violent crimes, a primary driver was racial differences in offending. Blacks committed homicides, rapes, robberies, and serious assaults at much higher rates than whites did. Much violent offending is intraracial. Failure to take black offenders' violent crimes seriously in effect would constitute indifference to black victims' violent victimization, and few people would want to do that. Racial disparities preponderantly based on offending differences were difficult to challenge on normative grounds.

There were two important caveats to the explanation that differences in racial offending explain differences in imprisonment. First, it applied mostly to serious violent offenses; for less serious offenses, offending explained much less of imprisonment disparities. For the most serious crimes, the crime itself appeared to be the primary factor explaining sentencing decisions, leaving comparatively little room for bias or stereotyping to operate. Less serious crimes allowed more room for discretionary decision making and the crime explained less. Second, for some crimes, arrest differences have no necessary link to offending differences; drug arrests are the most important example. Police can arrest street-level inner-city drug dealers almost at will, meaning that arrests are more a measure of police than of criminal activity. Disparities in arrests for drug offenses are the result of police policy choices.

The preceding paragraphs summarize analyses catalyzed by a landmark article by Alfred Blumstein (1982) that compared racial differences in arrests to racial differences in imprisonment, by offense and overall. It prompted additional more refined analyses by others (e.g., Langan 1985; Tonry 1995). The basic conclusion held up and was broadly confirmed by research on sentencing disparities that generally concluded that there are few racial differences in sentence lengths for offenders sent to prison (presumably mostly for more serious offenses and more chronic offenders); disparities are much more likely con- 
cerning the in/out decision (typically often concerning less serious offenses and offenders) (Blumstein et al. 1983; Spohn 2000; Harrington and Spohn 2007).

In this subsection, we summarize Blumstein's analysis, replicate the analysis for the year 2004, and consider other sources of data that might confirm or refute conclusions reached.

1. Blumstein's Original Analysis. Blumstein compared racial percentages among arrestees for particular offense categories to racial percentages among state prisoners sentenced following convictions for those offenses. Lots of questions can be raised as to whether arrests are a valid measure of offending (e.g., they might be systematically biased or erratically incomplete), whether jail inmates should have been taken into account, and whether they should be compared with racial patterns in prison admissions rather than in prison populations. ${ }^{8}$ We return to some of those questions below. First we present Blumstein's analysis.

Table 1 sets out Blumstein's original analysis and adds one additional column of information. Columns 1 and 2 show black/white percentages among people serving prison sentences in 1979 for 11 offense categories and overall. Columns 3 and 4 show black/white percentages of people aged 18 and up arrested in 1979 for those offense categories and overall. Column 6, which was not in Blumstein's analysis, compares the black percentages in the preceding columns and shows, for example, that black arrests for homicide account for all but 1.3 percent of the black percentage among people imprisoned for homicide. The unexplained variations among people imprisoned for robbery and aggravated assault are larger, but still small. For lesser assaults, auto theft, and burglary, the unexplained variation ranges from 16.6 to 29.8 percent, with the largest unexplained variation being for drug crime ( 36.7 percent).

Blumstein used a different analysis. Results are shown in column 5 . He compared black imprisonment relative to arrests to white imprisonment relative to arrests. Whites were relatively underrepresented in prison compared with their presence among arrestees (e.g., 47.7 percent of homicide prisoners but 48.5 percent of homicide arrestees; 57.7

\footnotetext{
${ }^{8}$ Blumstein (1982) identifies others. Use of aggregate national data, e.g., could camouflage stark differences between states (some of which might be very discriminatory, but this would pass unrecognized) and overlook offsetting racial biases (e.g., punishing blacks with white victims very harshly while punishing crimes involving black victims leniently or not at all).
} 
TABLE 1

Comparison of Crime-Specific Percentage of Blacks in State Prison and in Arrests, 1979

\begin{tabular}{|c|c|c|c|c|c|c|}
\hline \multirow[b]{2}{*}{ Crime } & \multicolumn{2}{|c|}{ Prisoners } & \multicolumn{2}{|c|}{ Arrests } & \multicolumn{2}{|c|}{$\begin{array}{c}\text { \% Black Prisoners } \\
\text { Unexplained by } \\
\text { Arrest }\end{array}$} \\
\hline & $\begin{array}{l}\text { White } \\
\text { (1) }\end{array}$ & $\begin{array}{l}\text { Black } \\
\text { (2) }\end{array}$ & $\begin{array}{l}\text { White } \\
\text { (3) }\end{array}$ & $\begin{array}{l}\text { Black } \\
(4)\end{array}$ & $\begin{array}{c}\text { Between } \\
\text { Races } \\
(5)\end{array}$ & $\begin{array}{c}\text { Within } \\
\text { Race } \\
(6)\end{array}$ \\
\hline $\begin{array}{l}\text { Murder and nonnegligent } \\
\text { manslaughter }\end{array}$ & 47.7 & 52.3 & 48.4 & 51.6 & 2.8 & 1.3 \\
\hline Forcible rape & 43.7 & 56.3 & 51.3 & 48.7 & 26.3 & 13.5 \\
\hline Robbery & 38.8 & 61.2 & 42.9 & 57.1 & 15.6 & 6.7 \\
\hline Aggravated assault & 57.7 & 42.3 & 59.0 & 41.0 & 5.2 & 3.1 \\
\hline Other violent & 53.1 & 46.9 & 60.9 & 39.1 & 27.3 & 16.6 \\
\hline Burglary & 57.7 & 42.3 & 67.1 & 32.9 & 33.1 & 22.2 \\
\hline Larceny/auto theft & 50.7 & 49.3 & 65.4 & 34.6 & 45.6 & 29.8 \\
\hline Other property & 64.4 & 35.6 & 65.4 & 34.6 & 4.3 & 2.8 \\
\hline Drugs & 60.5 & 39.5 & 75.0 & 25.0 & 48.9 & 36.7 \\
\hline Public order & 61.4 & 38.6 & 69.3 & 30.7 & 29.5 & 20.5 \\
\hline Other & 71.7 & 28.3 & 66.3 & 33.7 & -28.7 & -19.1 \\
\hline Total & 50.9 & 49.14 & 56.6 & 43.45 & 20.5 & 11.6 \\
\hline
\end{tabular}

SOURCE.-Blumstein (1982).

percent of burglary prisoners but 67.1 percent of burglary arrestees). He thus compared blacks' presence in prison given an arrest for a particular offense to whites' presence. Between-race calculations (col. 5) produce higher rates of unexplained variation than do within-race calculations (col. 6) (20.5 percent overall compared with 11.6), but the results using either calculation were inconsistent with the hypothesis that racial bias and stereotyping explained the largest part of disparities in imprisonment rates for serious crimes.

Two primary objections to Blumstein's analysis are that arrests may themselves be a biased basis for comparison and that prison population data reflect a combination of prison admission rates with sentence lengths. Patrick Langan (1985) explored these objections. His aim was to get behind arrests by looking at data on assailants identified by victims and, to avoid the confounding interaction effects of prison admission rates and average sentence lengths, by looking at prison admission rates alone. He compared data from the NCVS for 1973, 1979, and 1982 on victims' characterizations of their assailants' race with racially disaggregated data on prison admissions. Because victimization 
TABLE 2

Comparison of Crime-Specific Percentage of Blacks in State Prison and in Arrests, 2004

\begin{tabular}{|c|c|c|c|c|c|c|}
\hline \multirow[b]{2}{*}{ Crime } & \multicolumn{2}{|c|}{ Prisoners } & \multicolumn{2}{|c|}{ Arrests } & \multicolumn{2}{|c|}{$\begin{array}{c}\text { \% Black Prisoners } \\
\text { Unexplained by } \\
\text { Arrest }\end{array}$} \\
\hline & $\begin{array}{l}\text { White } \\
\text { (1) }\end{array}$ & $\begin{array}{l}\text { Black } \\
\text { (2) }\end{array}$ & $\begin{array}{l}\text { White } \\
\text { (3) }\end{array}$ & $\begin{array}{c}\text { Black } \\
(4)\end{array}$ & $\begin{array}{l}\text { Between } \\
\text { Races } \\
(5)\end{array}$ & $\begin{array}{l}\text { Within } \\
\text { Race } \\
(6)\end{array}$ \\
\hline $\begin{array}{l}\text { Murder and nonnegligent } \\
\text { manslaughter }\end{array}$ & 48.9 & 51.1 & 52.0 & 48.0 & 11.6 & 6.0 \\
\hline Forcible rape & 61.7 & 38.3 & 67.7 & 32.3 & 23.2 & 15.7 \\
\hline Robbery & 37.6 & 62.4 & 49.0 & 51.0 & 37.2 & 18.2 \\
\hline Assault & 53.3 & 46.7 & 73.5 & 26.5 & 58.8 & 43.2 \\
\hline Burglary & 59.1 & 40.9 & 72.6 & 27.4 & 45.5 & 33.0 \\
\hline Larceny/theft & 58.8 & 42.2 & 71.1 & 28.9 & 44.3 & 31.5 \\
\hline Motor vehicle theft & 63.3 & 36.7 & 67.4 & 32.6 & 16.7 & 11.2 \\
\hline Drugs & 45.5 & 54.5 & 66.2 & 33.8 & 57.4 & 38.0 \\
\hline Violent crime & 52.1 & 47.9 & 63.9 & 36.1 & 38.4 & 24.6 \\
\hline Property crime & 60.3 & 39.7 & 71.1 & 28.9 & 38.3 & 27.3 \\
\hline Total & 53.2 & 46.8 & 65.0 & 35.0 & 38.9 & 25.3 \\
\hline
\end{tabular}

SOURCES.-Federal Bureau of Investigation (2005); BJS (2006).

NOTE.-Changes in BJS and FBI offense classifications since 1979 required that we estimate some numbers. We believe that we have closely approximated Blumstein's original calculations.

data do not include homicide and rape numbers in victimization data are too small to permit meaningful analyses, he looked at robbery, aggravated assault, and three property crimes. For robbery, his findings paralleled Blumstein's: victims' reports on offenders' race and prison admission data by race were nearly identical. Like Blumstein, Langan concluded that about 80 percent of racial disparity was explainable by reference to offending patterns and, overall, that "test results generally support the differential involvement [in crime] hypothesis" (p. 678).

2. Replication Using 2004 Data. We replicated Blumstein's analysis using arrest and prison population data for 2004. Table 2 shows the results. A much smaller part of racial disparities in imprisonment can be explained by arrest patterns in 2004 than Blumstein found for 1979. In Blumstein's between-race comparisons, arrests explained all but 2.8 percent of imprisonment disparities in homicide imprisonment; 11.6 percent remained unexplained in 2004. For robbery in 1979, 15.6 percent of imprisonment disparities went unexplained; in 2004, 37.2 per- 


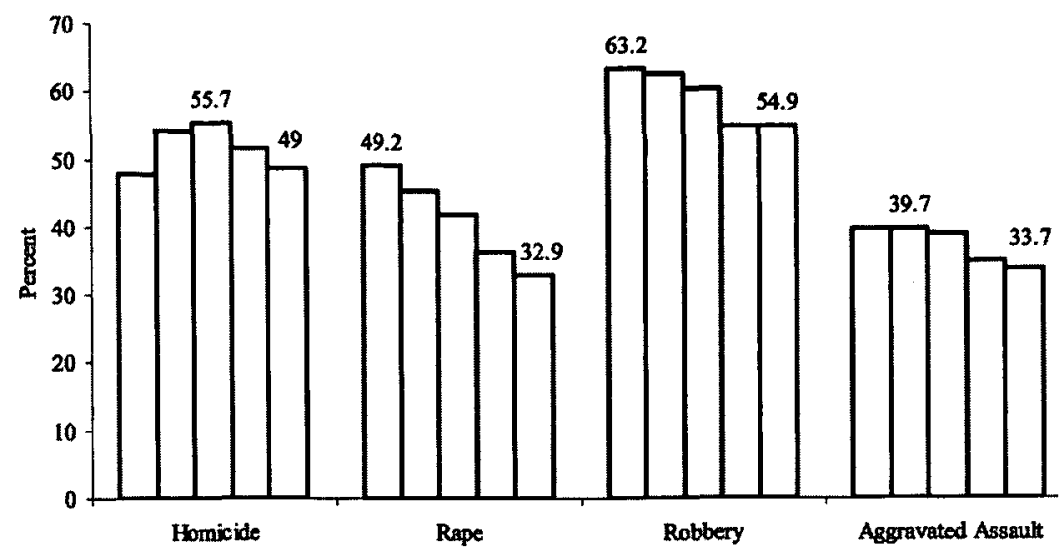

FIG. 6.-Black percentages among Uniform Crime Report violent index arrestees, 1982-2006 (5-year averages). Source: Federal Bureau of Investigation, Crime in the United States, various years.

cent. Overall, Blumstein's 1979 analysis left 20.5 percent of imprisonment disparities unexplained. He replicated the analysis using 1991 data and concluded that unexplained disparities had increased to 25 percent (Blumstein 1993). Our 2004 analysis left 38.9 percent unexplained. Had Blumstein in his 1982 article found unexplained disparities as large as we find for 2004 , surely his conclusion would have been the opposite of what it was: such large unexplained variation creates a strong presumption of racial bias.

In trying to understand why the results are so different for 2004, we looked at racial trends in arrest patterns. Perhaps black percentages among arrestees for serious crimes rose rapidly after 1979, with black percentages in 2004 being anomalously low. As figure 6 shows, however, the opposite is true. Black Americans' involvement in violence is declining. The figure shows black percentages, averaged over 5-year periods, among people arrested for homicide, forcible rape, robbery, and aggravated assault. Although black Americans continue to be overrepresented among arrestees, the degree of overrepresentation has been falling for a quarter century. Fifty-six percent of homicide arrestees in 1992-96 were black; 49 percent were in 2002-6. In 1982-86, 49 percent of rape arrestees were black; 33 percent were in 2002-6. The declines are almost as steep for robbery and aggravated assault. That's 


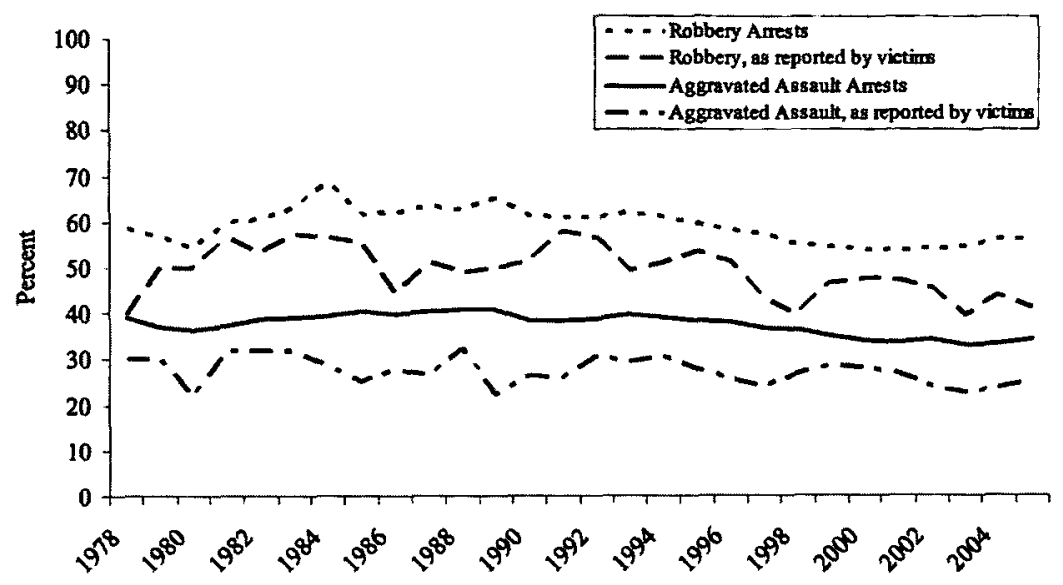

FIG. 7.-Percentage of blacks among lone offenders as perceived by victims and percentage of black arrests, 1978-2005. Sources: BJS, Sourcebook of Criminal 7ustice Statistics (http://www.albany.edu/sourcebook/), various years; Federal Bureau of Investigation, Crime in the United States, various years.

good news: black involvement in serious violent crime has been declining.

Perhaps, we thought, the explanation is to be found in changes in arrest data that operated to underreport black violence. To check this, using NCVS data we compared arrest percentages with robbery and aggravated assault victims' characterizations of the racial characteristics of their assailants. Figure 7 shows the result: no significant change in a quarter century. Black percentages among arrestees for both offenses have consistently tracked victims' characterizations but been higher. The reason is at least in part that many robberies and assaults involve more than one assailant, and the NCVS data pertain to crimes involving lone offenders.

So why are so many blacks in prison compared with whites? That question can be answered at (at least) two levels. The first, which we discuss in the remaining portion of this section, is mechanical: what are the mechanisms that put more blacks in prison than their population or crime participation percentages appear to justify? The second, which we discuss in Section II, is more difficult: what is it about American society and cultural norms that allowed those mechanisms to exist and allows them to persist? 


\section{What Are the Direct Causes of Racial Disparities in Imprisonment?}

There are four plausible explanations for why there are so many more black prisoners than offending patterns suggest there should be. First, invidious bias and conscious stereotypes ("Many young black men are dangerous, so I must treat this young black man harshly") may cause police, prosecutors, and judges to treat black defendants more severely than they treat whites. Second, subtler forms of subconscious stereotyping and attribution may be operating. Third, disparities may be worsened by police practices that disproportionately affect blacks. Fourth, disparities may be worsened by sentencing policies relating to violent and drug crimes.

1. Bias and Conscious Stereotyping. We have the least to say about this hypothesis. No doubt some Americans, including some public officials, are racists and are biased against blacks. Larger numbers are no doubt affected by conscious stereotypes about blacks. Still more engage in "statistical discrimination," the attribution of traits that characterize groups to individual members of groups. This is one central issue in analyses of racial profiling. If many young black men in particular neighborhoods, who adopt particular styles of dress, are involved in gang activities or drug dealing, police seeing a young man in that neighborhood who fits that pattern may believe it likely that he is a gang member or drug dealer and stop him, even if the individualized basis for a stop that the law requires does not exist. To a police officer, this may seem an obvious and sensible thing to do. To a civil libertarian, such a stop is an obvious and intolerable instance of crude racial stereotyping. Efforts to establish from police stop data whether "yields" or "hit rates" for blacks and whites stopped by the police are higher or lower effectively assume that this form of statistical stereotyping could be acceptable: if blacks are stopped at twice the rate of whites but contraband is found in the same or a higher percentage of cases, that implicitly demonstrates that police are not acting in an invidious way but have valid reasons more often to be suspicious of blacks.

The effects of bias and stereotyping are likely to be different at police and sentencing stages. Research on profiling generally concludes that police do stop blacks disproportionately often on the streets and on the highway, generally do not achieve higher hit rates for blacks than for whites (e.g., Engel and Calnon 2004), but usually make more arrests. Inevitably this means that police practices lead to higher levels of black arrests, and therefore convictions and prisoners, than would 
otherwise exist. These practices are particularly likely to worsen racial disparities for drug and firearms offenses since those are the two kinds of illegal contraband police stops are most likely to yield. We discuss this further below in relation to drug policy.

On the basis of personal interactions over decades with judges in many American jurisdictions, we do not believe that invidious racial bias and gross stereotypes are likely substantially to affect sentencing decisions. This is a subject judges worry about and discuss often among themselves and with others. Sentencing research showing that there are few racial differences in sentence lengths is consistent with our belief (e.g., Spohn 2000, 2002). Sentencing research showing that there are often in/out differences is not necessarily strongly inconsistent with it. Black defendants, especially young ones, often have more extensive criminal records than whites, and judges take criminal records into account when deciding which defendants "deserve another chance." Similarly, black defendants on average have less stable home lives, less conventional employment records, and fewer educational attainments than whites, and judges take such things into account in deciding which defendants are more likely to succeed in community sentences and programs and which are more likely to reoffend. ${ }^{9}$

2. Unconscious Stereotyping and Attribution. In some ways it is surprising that the literature on sentencing disparities shows comparatively few differences in outcomes on the basis of race. Recent research on "colorism" and the significance of Afrocentric features in stereotyping offenders shows that stereotypes are deeply embedded in American culture and affect both white and black people (the fullest examination of this literature can be found in Blank, Dabaddy, and Citro [2004]). Analysts of "Afrocentric feature bias" posit that certain stereotypically African American facial features influence decision makers' (and research subjects') judgments about individual offenders. Although the number of studies is small, their implications are disturbing. One study found that people with more Afrocentric features appeared more "criminal" to observers and that the more Afrocentric features

\footnotetext{
${ }^{9}$ Our point in the text is not that the practices described in this and the preceding sentence are necessarily unobjectionable, but that many judges engage in them in good faith. Argument can be made that black defendants acquire more extensive criminal records at younger ages than whites because police are more likely to arrest them, and accordingly that the criminal record at least in part is more a product of police than of criminal activity, and in fairness should not be held against black defendants. Similarly, objections have long been made to taking account of social factors (household stability, employment, education) in sentencing, precisely because they are correlated with race.
} 
an individual possessed, the more "criminal" he appeared (Eberhardt et al. 2004). In other studies, Afrocentric features were associated with longer prison sentences and increased frequency of capital sentencing (Blair, Judd, and Fallman 2004; Eberhardt et al. 2006). ${ }^{10}$

The study of Afrocentric feature bias emerged from research on "colorism," discrimination within racial groups on the basis of gradations in skin color (Jones 2000). Many studies have shown that people associate lighter skin tones among blacks with positive characteristics and darker skin tones with negative characteristics (e.g., Maddox and Gray 2002), but no published work has investigated colorism in criminal justice settings.

Several recent studies have tried to assess the significance of Afrocentric feature bias. Blair et al. (2002) found that individuals with more Afrocentric features were judged by college undergraduates to have stereotypical African American traits. Blair, Chapleau, and Judd (2005) showed that research subjects believed that individuals with more Afrocentric features were likely more often than others to behave aggressively.

Eberhardt et al. (2004) asked 182 police officers to examine photographs of male students and employees at Stanford University. Half were shown white faces and half were shown black faces. One-third of the officers were asked to rate the stereotypicality of each face on a scale, that is, how stereotypical each face was of members of the person's race. Another third, told that some of the faces might be of criminals, were asked to indicate whether the person "looked criminal." The last third were asked to rate attractiveness on a scale. Each officer completed only one of the three measures.

More black than white faces were thought to look criminal. Black faces rated above the median for stereotypicality were judged as criminal significantly more than were black faces rated below the median. The opposite was found for white faces. The authors concluded that the police officers thought that black faces looked more criminal and that "the more black, the more criminal" (Eberhardt et al. 2004, p. 889).

Blair, Judd, and Chapleau (2004) analyzed the Afrocentric features

\footnotetext{
${ }^{10}$ Another explanation is that many biases people harbor are not consciously accessible. The Implicit Association Test, which has been used to assess implicit attitudes toward different groups, has shown a significant implicit preference for whites among all races and ethnicities (Greenwald and Krieger 2006).
} 
of inmates in the Florida Department of Corrections database. They asked undergraduates to rate the faces of a randomly selected sample of 216 inmates, 100 black and 116 white, in terms of the "degree to which each face had features that are typical of African Americans" (p. 676). After they controlled for race and criminal history, Afrocentric features were a significant predictor of sentence length. Within each race, more Afrocentric features were associated with longer sentences. ${ }^{11}$

Pizzi, Blair, and Judd (2005, p. 351) argued that judges and prosecutors have adapted to differences between racial groups but have not been sensitized to sentencing differences on the basis of Afrocentric features: "Racial stereotyping in sentencing decisions still persists. But it is not a function of the racial category of the individual; instead, there seems to be an equally pernicious and less controllable process at work. Racial stereotyping in sentencing still occurs based on the facial appearance of the offender. Be they White or African American, those offenders who possess stronger Afrocentric features receive harsher sentences for the same crimes."

Eberhardt et al. (2006, p. 383), using a database of death-eligible cases in Philadelphia, "examined the extent to which perceived stereotypicality of Black defendants influenced jurors' death-sentencing decisions in cases with both White and Black victims." Stanford undergraduates were shown pictures of 44 defendants, presented randomly and edited for uniformity, and asked to rate the stereotypicality of each black defendant's appearance. With stereotypicality as the only independent variable, 24.4 percent of black defendants rated below the median for stereotypicality received a death sentence, compared with 57.5 percent of black defendants rated above the median.

3. Drug Policy. American drug policies are a primary aggravator of racial disparities in imprisonment. Blumstein's 1982 analysis of 1979 prison population showed that arrest patterns for drug offenses explained the smallest percentage of racial disproportionality in imprisonment (48.9 percent unexplained) of any offense category at a time when 5.7 percent of prisoners (about 16,000 total) had been convicted of drug crimes (see table 1). Our analysis of 2004 data again showed

\footnotetext{
"Blair, Judd, and Fallman (2004, p. 677) note, however, that this does not necessarily imply explicit bias: "this form of stereotyping appears to occur without people's awareness and outside their immediate control."
} 


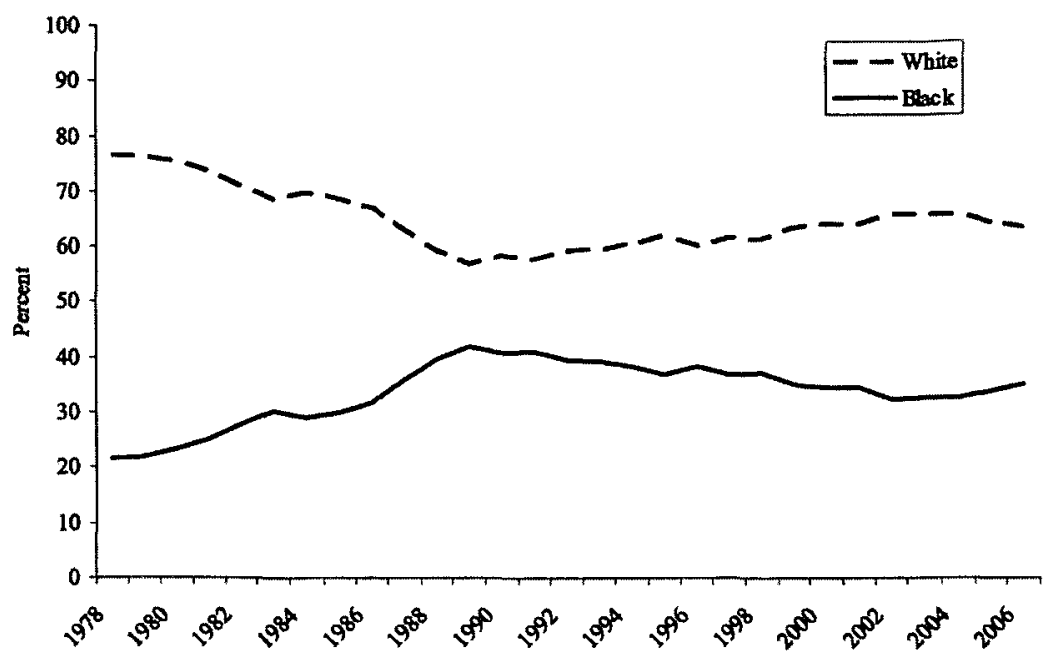

Fig. 8.-Total arrests for drug offenses, by race, 1978-2006. Sources: BJS, Sourcebook of Criminal Fustice Statistics (http://www.albany.edu/sourcebook/), various years; Federal Bureau of Investigation, Crime in the United States, various years.

that drug arrests explained the smallest percentages of prison disproportionality (57.4 percent unexplained; see table 2). ${ }^{12}$

Figures 8 and 9 show why the black imprisonment rate for drug crimes is so high. Figure 8 shows black and white percentages among people arrested for drug crimes between 1978 and 2006. As recently as 1978 , approximately 80 percent of adult drug arrestees were white. By 1989 , the black share among all arrestees exceeded 40 percent, and in the years since it has fluctuated between 32 and 40 percent. How does it happen that 13 percent of the population make up 40 percent of drug arrestees?

The answer is that blacks are much more likely than whites to be arrested for drug crimes. Figure 9 shows total arrest rates of blacks and whites from 1978 to 2006 . The white rate since 1978 has been approximately one-fourth the black one. Why are blacks so much more often arrested for drug crimes?

The answer is not, as table 3 shows, that blacks use drugs at much

${ }^{12}$ For assaults, 58.8 percent of disproportionality went unexplained, no doubt partly because assaults in 2004 were not limited to aggravated assaults as in Blumstein's (1982) data but included a substantial preponderance of less serious events. 


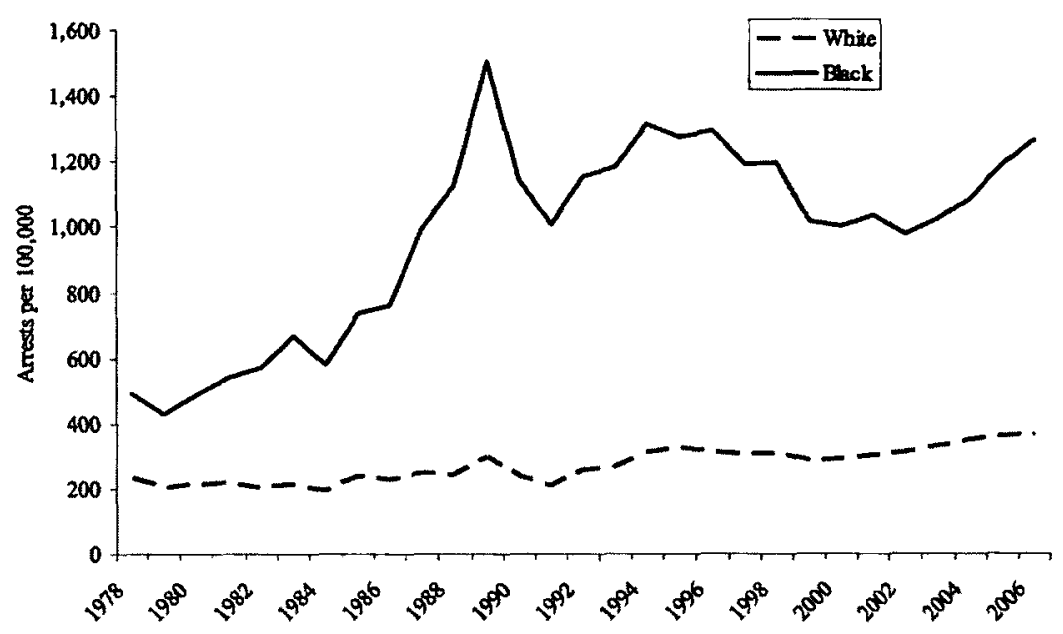

FIG. 9.--Total arrest rate for drug offenses, by race, 1978-2006. Sources: BJS, Sourcebook of Criminal fustice Statistics (http://www.albany.edu/sourcebook/), various years.

higher rates than whites do. National Institute of Drug Abuse surveys have tracked self-reported drug use since the 1970s. The table shows percentages of blacks and whites who reported using alcohol, any other drugs, and four categories of illicit substances ever, in the last year, and in the last month. In 2005 and 2006, larger percentages of whites reported using alcohol, cocaine (including crack), and hallucinogens, and the differences are large. Larger percentages of whites than blacks report having ever used marijuana, and slightly higher percentages of blacks report using marijuana recently. Only for crack (considered alone) do blacks report significantly higher use levels than whites, but the absolute levels are low. One conclusion is clear: the reason so many more blacks than whites are arrested or imprisoned for drug crimes is not that they use drugs much more extensively than whites do.

Another plausible reason why blacks might more often be arrested for drug crimes than are whites is that they are much more extensively involved in drug trafficking. National Institute of Drug Abuse (NIDA) surveys based on representative samples of the U.S. population indicate that this is not true. ${ }^{13}$ Figure 10 shows self-reported drug selling by

\footnotetext{
${ }^{13}$ In recent years, reports of the National Survey on Drug Use and Health have identified the author as the Office of Applied Studies, Substance Abuse and Mental Health
} 
TABLE 3

Percentage of Drug Use, by Race, 2005-6

\begin{tabular}{|c|c|c|c|c|}
\hline \multirow[b]{2}{*}{ Drug } & \multicolumn{2}{|c|}{2005} & \multicolumn{2}{|c|}{2006} \\
\hline & White & Black & White & Black \\
\hline \multicolumn{5}{|l|}{ Alcohol: } \\
\hline Ever used & 86.9 & 75.2 & 86.9 & 75.4 \\
\hline Within last year & 70.5 & 55.5 & 70.4 & 55.1 \\
\hline Within last month & 56.5 & 40.8 & 55.8 & 40.0 \\
\hline \multicolumn{5}{|l|}{ All illicit drugs:* } \\
\hline Ever used & 48.9 & 44.7 & 49.0 & 42.9 \\
\hline Within last year & 14.5 & 16.0 & 14.8 & 16.4 \\
\hline Within last month & 8.1 & 9.7 & 8.5 & 9.8 \\
\hline \multicolumn{5}{|l|}{ Marijuana: } \\
\hline Ever used & 43.7 & 39.0 & 43.9 & 37.6 \\
\hline Within last year & 10.6 & 12.3 & 10.7 & 12.4 \\
\hline Within last month & 6.1 & 7.6 & 6.4 & 7.4 \\
\hline \multicolumn{5}{|l|}{ Cocaine: ${ }^{\dagger}$} \\
\hline Ever used & 15.5 & 9.8 & 16.3 & 9.1 \\
\hline Within last year & 2.4 & 2.0 & 2.5 & 2.1 \\
\hline Within last month & 1.0 & 1.1 & .9 & 1.3 \\
\hline \multicolumn{5}{|l|}{ Crack: } \\
\hline Ever used & 3.2 & 4.9 & 3.3 & 5.3 \\
\hline Within last year & .5 & 1.2 & .5 & 1.3 \\
\hline Within last month & .2 & .8 & .2 & .8 \\
\hline \multicolumn{5}{|l|}{ Hallucinogens: } \\
\hline Ever used & 16.3 & 6.5 & 17.0 & 6.6 \\
\hline Within last year & 1.8 & .8 & 1.7 & 1.4 \\
\hline Within last month & .5 & .2 & .4 & .5 \\
\hline
\end{tabular}

SOURCE.- Office of Applied Studies, National Survey on Drug Use and Health, various years.

* Illicit drugs include marijuana/hashish, cocaine (including crack), heroin, hallucinogens, inhalants, or prescription-type psychotherapeutics used nonmedically.

${ }^{\dagger}$ Includes crack cocaine.

12-17-year-old blacks and whites for the years 2001-6. Three to four percent of both groups reported selling drugs at least once in the preceding year, and 1 percent reported selling drugs at least 10 or more times during the preceding year. The black and white rates for most measures are nearly identical; on average for the entire period and for most years, white rates are slightly higher than black rates.

Representative national surveys undercount transient and homeless

Services Administration, which is how we refer to data from the survey in source notes. Predecessor surveys were published by the NIDA. Because most readers will be more familiar with that attribution, we refer to NIDA when discussing survey data in the text. 


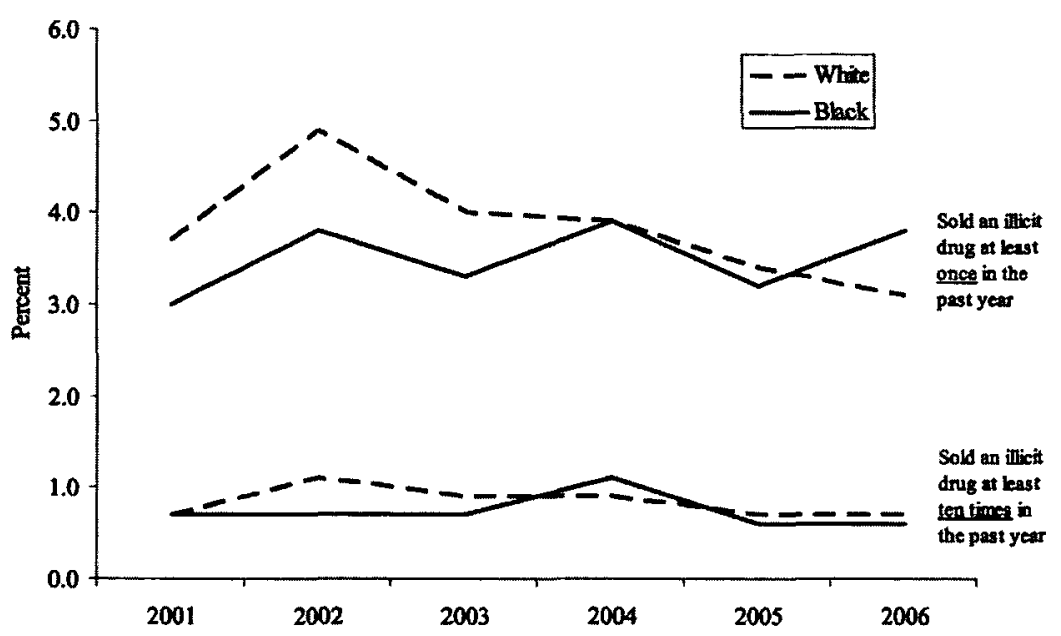

FIG. 10.-Illicit drug sales among youths aged 12-17, by race, 2001-6. Source: Office of Applied Studies, National Survey on Drug Use and Health, various years.

populations and do not count institutionalized populations (in prisons, jails, or mental institutions) at all. The effect is that measures that distinguish black and white rates may undercount black rates because relatively more blacks than whites have no permanent address and are confined in institutions. These problems, however, are much less significant for 12-17-year-olds, most of whom live with a parent or caretaker and few of whom are confined in institutions. However, even if these sampling problems to some degree affect the data in figure 10, they are unlikely to change significantly the drug trafficking patterns shown; for example, increasing black rates by 25 percent would not materially alter the black/white comparisons. It would make the black rates slightly higher than the white rates rather than slightly lower.

The reason why so many more blacks than whites are arrested and imprisoned for drug crimes is well known and long recognized. They are much easier to arrest. Much white drug dealing occurs behind closed doors and in private. Much black drug dealing occurs in public or semipublic, on the streets and in open-air drug markets. And much black drug dealing occurs between strangers. Figures 11 and 12 present NIDA self-report data for the total population for 2001-6 on locations and sources of subjects' most recent marijuana purchases. As figure 12 shows, in each year, 87-88 percent of whites made their purchases from 


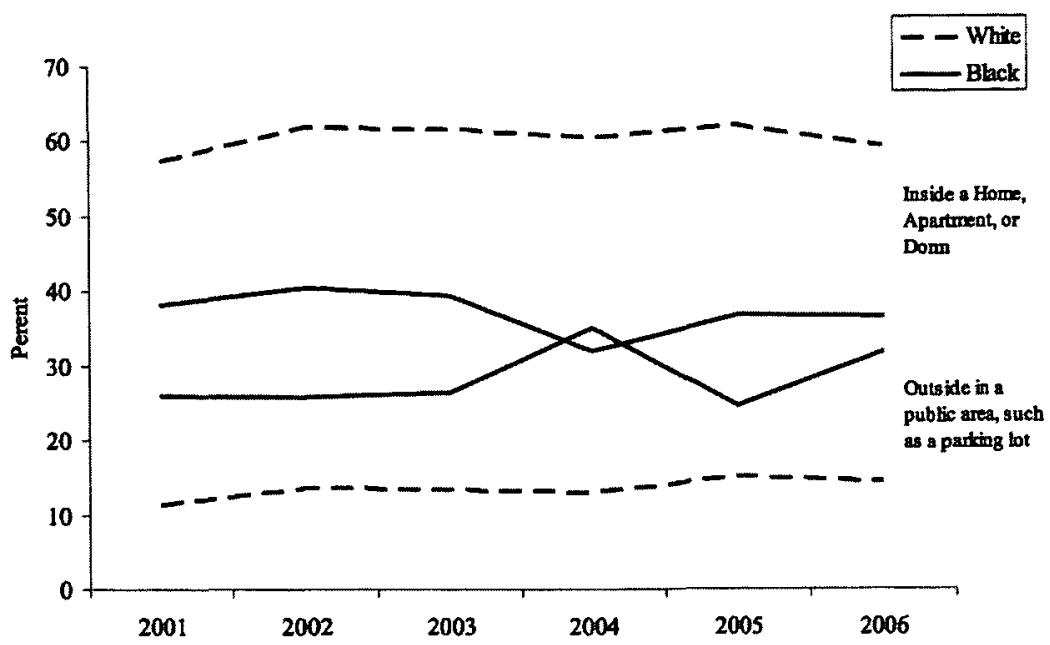

FIG. 11.-Location of last purchase of marijuana, by race, 2001-6. Source: Office of Applied Studies, National Survey on Drug Use and Health, various years. Categories do not account for 100 percent of purchases because the following response categories were excluded: inside a public building, such as a store or restaurant; inside a school building; outside on school property; and some other place.

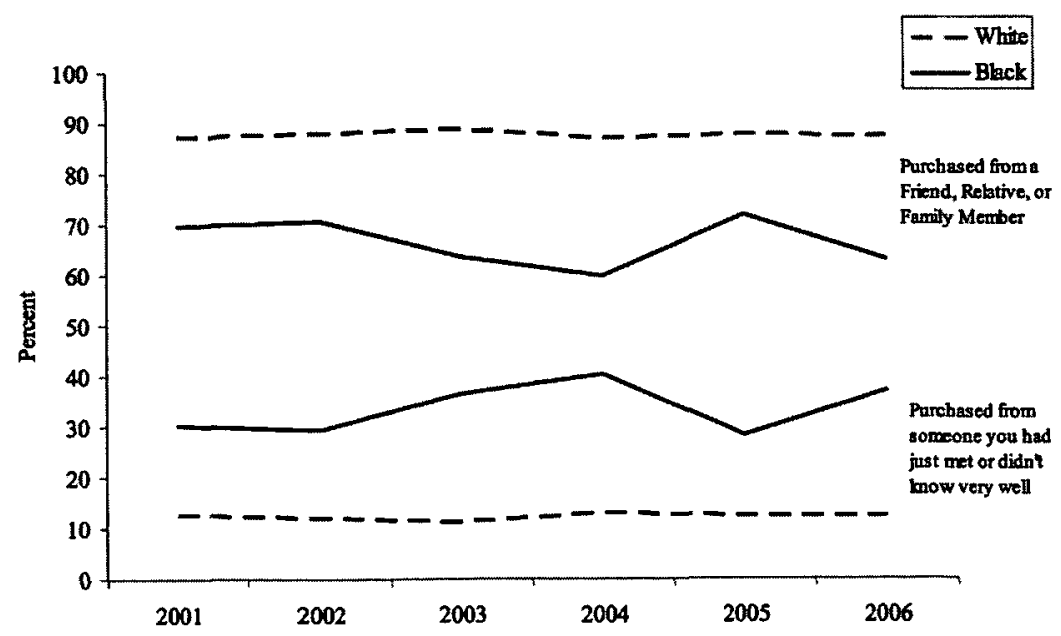

FIG. 12.-Source of last purchase of marijuana, by race, 2001-6. Source: Office of Applied Studies, National Survey on Drug Use and Health, various years. 
friends, relatives, and family members. By contrast, blacks purchased marijuana from people they had just met or did not know well 30-40 percent of the time.

Figure 11 presents data on where marijuana is purchased. Depending on the year, 57-62 percent of purchases by whites occurred inside a home, apartment, or dorm, and only 11-14 percent outdoors in public spaces such as parking lots. For black purchasers, the pattern was starkly different. Forty percent or less of purchases occurred in private indoor spaces; 26-35 percent were made outdoors in public spaces.

Undercover drug agents can penetrate black urban drug markets relatively easily and make arrests almost at will. Most white drug dealing, by contrast, occurs within existing social networks in which people know one another, and in private. Undercover agents have to invest much more time in establishing their bona fides; the arrest yield from a fixed amount of time or effort is much lower when pursuing white than when pursuing black sellers.

In other words, black arrest rates are so much higher than white rates because police choose as a strategic matter to invest more energy and effort in arresting blacks. So many more blacks than whites are in prison because police officials have adopted practices, and policy makers have enacted laws, that foreseeably treat black offenders much more harshly than white ones.

4. Sentencing Policies for Violent and Drug Crimes. Sentencing policies for drug crimes and violent crimes have been a major driver of racial disparities in imprisonment since the mid-1970s. Until the early 1980s, the tougher laws mainly established mandatory minimum sentences for violent and gun crimes, but the minimums were usually 1 or 2 years or at most 5 (Shane-DuBow, Brown, and Olsen 1985). Beginning in the mid-1980s and continuing through the mid-1990s, epitomized by the federal 100-to-one law governing cocaine sentencing and California's three-strikes law that required sentences ranging from 25 years to life for third felonies, sentences for drugs, guns, and violence were made incomparably harsher.

Black Americans have borne the brunt of this tougher sentencing. For drug crimes, as we have already shown, police arrest policies produce arrest rates for blacks that are far out of proportion to blacks' drug use or involvement in drug trafficking. For understandable reasons of social disadvantage and limited life chances, blacks engage more 
TABLE 4

New Commitments to State Prisons, by Race, 2003

\begin{tabular}{lcccc}
\hline & All & Black* & White* $^{*}$ & Hispanic $^{+}$ \\
\hline Violence, of which & $28.2 \%$ & $27.7 \%$ & $26.1 \%$ & $34.9 \%$ \\
Homicide & 2.9 & 2.9 & 2.5 & 3.5 \\
Robbery & 7.6 & $\mathbf{1 0 . 4}$ & 4.7 & $\mathbf{8 . 3}$ \\
Property & 27.9 & 24.2 & 32.8 & 22.2 \\
Drugs & 30.7 & 37.5 & $\mathbf{2 5 . 5}$ & $\mathbf{3 0 . 6}$ \\
Public order, of which & 12.7 & 10.2 & 15 & 11.8 \\
$\quad$ Guns & 3.3 & 4.2 & 2.1 & 3.7 \\
All & 100 & 100 & 100 & 100 \\
\hline
\end{tabular}

SOURCE.-BJS, National Corrections Reporting Program—2003 (fíncrp0304.csv), table 4.

* Includes persons of Hispanic origin.

${ }^{\dagger}$ Includes persons of all races.

often in gun crimes and serious violent crimes. Laws that increase sentences for such crimes inevitably exacerbate racial disparities.

Table 4, for example, shows new state prison commitments by conviction offense and race for 2003, the most recent year for which data are available from the BJS National Corrections Reporting Program. Among whites, 53.7 percent were committed for violent, drug, or gun crimes, compared with 69.4 percent of black offenders (in both cases including Hispanic same-race offenders). The racial skew is even greater when the focus is narrowed to robbery, drugs, and guns $(52.1$ percent of black prisoners, 32.3 percent of whites). Among black prisoners, 37.5 percent were committed for drug crimes; among white prisoners, 25.5 percent were.

There have long been good reasons to believe that longer sentences for drug crimes have no effect on levels of drug use, drug prices, or drug trafficking (e.g., Wilson 1990; Dills, Miron, and Summers 2008; MacCoun and Martin, forthcoming). And there are good reasons to doubt that increasing penalties for particular violent or drug crimes from 3 years to 5,5 years to 10 , or 10 years to 20 has any discernible effects on crime rates (e.g., Doob and Webster 2003; Dills, Miron, and Summers 2008; Tonry, in this volume). Those things being true, to increase penalties for crimes with which blacks are charged, for whatever reason, is to increase racial disparities in prison for no good reason or for a not well-justified one.

5. In Sum. Black Americans suffer from imprisonment rates six to seven times higher than those of whites primarily for two reasons. 
Police arrest policies for drugs target a type of drug trafficking (streetlevel transactions in inner-city areas) in which blacks are disproportionately involved. American sentencing laws and policies specify punishments that are both absolutely and relatively severe for violent, drug, and gun crimes for which blacks are more likely than whites to be arrested and prosecuted. Conscious bias and stereotyping, and unconscious stereotyping and attribution, no doubt play some roles in causing disparities, but smaller ones.

\section{Making Sense of Racial Disparities}

A primary aim of this essay was to see how patterns of racial disparity have changed since the mid-1990s. We learned three important things that provided one bit of good news and two of terrible news. The good news is that patterns of racial involvement in serious crime as shown in arrest data have changed. The percentages of people arrested for aggravated assault, robbery, rape, and homicide who are black have been declining and in 2006 were much lower than in 1985. One might hope, and expect, that racial disparities in imprisonment would have fallen commensurately.

The two bits of terrible news: The first is that blacks continue to make up about half of the prison population ${ }^{14}$ and about the same percentage of Death Row inmates as in the 1980s. The chance that a black American is in prison in 2007 remains six to seven times higher than the chance that a white American is in prison. The declining involvement of blacks in serious violent crime has had no effect on racial disparities in prison.

The second is that insensitivity to the interests of black Americans continues to characterize American crime policies. Racial disparities in imprisonment continue to be generated by policy choices that were known, or should have been known, disproportionately to affect disadvantaged black Americans. In no significant respect have American drug policies changed since the 1980 s-the federal 100 -to-one rule is

${ }^{14}$ BJS (2007) data for midyear 2006 show that black men constituted 41 percent of male jail and prison inmates. The true figure in a country in which skin color matters much more than ethnicity is $46-48$ percent (because a few years ago the BJS stopped counting black Hispanics as black and thereby reduced the black percentage by $10-12$ percent; a quarter to a third of imprisoned Hispanics, who made up 21 percent of male inmates, are dark skinned). Forty-seven percent is to be sure less than 50 and is the result of the rapid increase in imprisonment of Hispanic people in recent years. There were more non-Hispanic blacks than non-Hispanic whites imprisoned in 2007. 
the symbol of that-and they continue grossly disproportionately to ensnare young blacks and, increasingly, young Hispanics. ${ }^{15}$ And American policies toughening penalties for violent crime have had the same effect. If the conditions of life faced by disadvantaged minority youths make them disproportionately likely to be involved in violent crime, then policies making punishments for violent crime enormously harsher will disproportionately affect them, and they have.

Loïc Wacquant's work provides insight into how that happened. ${ }^{16}$ For a decade now, he has been writing articles on race and crime control policy. His basic argument is that American cultural practices and legal institutions have operated to maintain patterns of racial dominance and hierarchy for two centuries. Until the Civil War, slavery assured white domination. Within 30 years after the war, the practices and legal forms of discrimination known as "Jim Crow" laws restored white domination of blacks. In the "Great Migration" in the 1910s and 1920 s, millions of blacks moved from the South to the North to escape Jim Crow; the big city ghettos, housing discrimination, and other forms of discrimination kept blacks in their subordinate place (Lieberson 1980). And when deindustrialization and the flight of jobs to the suburbs left disadvantaged blacks marooned in the urban ghettos, the modern wars on drugs and crime took over (Wacquant 2002a, 2002b).

Wacquant's writing is passionate and controversial, but it is time more people paid attention to it. The civil rights movement has borne fruit in the forms of increased economic and social integration of blacks in American society. The progress made is remarkable in light of the justice system experiences of black Americans.

Wacquant's argument is a functionalist one, about what criminal justice policies and practices do, rather than a political one about what

${ }^{15}$ The U.S. Sentencing Commission (2007) revisions to its crack and cocaine guidelines merely nibble at the edges of the disparities caused by the 100 -to-one statute: "The sentencing commission's striking move on Tuesday, meant to address the wildly disproportionate punishments for crack and powder cocaine, will have only a minor impact. Unless Congress acts, many thousands of defendants will continue to face vastly different sentences for possessing and selling different types of the same thing" (Liptak 2007, p. A21).

${ }^{16}$ We do not here discuss features of American politics that made racial insensitivity more explicable in the last 30 years: the political ascendancy of the right wing of the Republican Party, embodying the contemporary resurgence of what Richard Hofstadter (1965) called the "paranoid streak in American politics," and the influence on it of fundamentalist Protestants. If crime and drugs are matters of good and evil, and criminals and drug users are evil, then there is little reason to expect sympathy or empathy toward them from the holders of those views (especially if the criminals and drug users are black and different). See Tonry (2008). 
those practices and policies are intended to do. Thought of that way, thinking of what the machinery of the criminal justice system produces, it is hard not to see that it produces devastatingly reduced life chances for black Americans. If its aims were to reduce disadvantaged black men's chances of earning a decent living, or being successfully married and a good father, or being socialized into prosocial values, it is hard to see how the criminal justice system could do those things better (Western 2006). There has to be a reason why the criminal justice system treats American blacks so badly, why its foreseeable disparate impacts on blacks and whites are disregarded, and Wacquant's analysis provides a better explanation than any other that has been offered.

Wacquant's passion sometimes makes it easy for critics to dismiss his arguments as polemics. $\mathrm{He}$ is, however, no longer alone in suggesting that American criminal justice practices operate to keep poor blacks in their places. Here is what Douglas Massey, author (with Nancy Denton) of American Apartbeid (1993), a widely praised and decidedly nonpolemical account of housing discrimination, had to say in Categorically Unequal, his 2007 book on social stratification:

Whether whites care to admit it or not, they have a selfish interest in maintaining the categorical mechanisms that perpetuate racial stratification. As a result, when pushed by the federal government to end overt discriminatory practices, they are likely to innovate new and more subtle ways to maintain their privileged position in society. If one discriminatory mechanism proves impossible to sustain, whites have an incentive to develop alternatives that may be associated only indirectly with race and are therefore not in obvious violation of civil rights law. The specific mechanisms by which racial stratification occurs can thus be expected to evolve over time. (P. 54)

[The] new emphasis on retribution and punishment was achieved . . . through the deliberate racialization of crime and violence in public consciousness by political entrepreneurs. (P. 94)

As discrimination moved underground, new mechanisms for exclusion were built into the criminal justice system for Afro Americans. (P. 251)

And, to complete this span of the political spectrum, here is what Glenn C. Loury, a conservative black economist and the author of The 
Anatomy of Racial Inequality (2002), had to say in introducing his 2007 Tanner Lectures at Stanford:

We have embraced what criminologist Michael Tonry calls a policy of "malign neglect," and in doing so we, as a society, have stumbled more or less wittingly into a God-awful cul de sac. I will claim that the connection of this apparatus to the history of racial degradation and subordination in our country (lynching, minstrelsy, segregation, ghetto-ization) is virtually self-evident, and that the racial subtext of our law and order political discourse over the last three decades has been palpable. (Loury 2007, p. 9; references omitted)

There are also psychological explanations for racial disparities' persistence. System justification theory posits "a general human tendency to support and defend the social status quo, broadly defined" (Blasi and Jost 2006, p. 1123). People, regardless of their situation, try to rationalize the injustices and inequities they see (Chen and Tyler 2002). Stereotypes (such as that the rich are smart and the poor are lazy) are often employed to demonstrate that all members of the system deserve their status. Concerning the criminal justice system, about which concern about racial disparities in imprisonment might be expected, comfort can be found in racial stereotypes, such as that black Americans are especially criminal, so of course many of them are in prison.

The incentive to rationalize is clear. People who believe in a just system experience, by and large, more positive emotions than people who blame the system. For example, poor people who blame themselves for their own poverty are happier and more satisfied with life in general (Blasi and Jost 2006, p. 1141). By rationalizing the inequities one sees in American sentencing, one finds mental comfort.

A considerable literature on racial differences in attitudes toward and opinions about crime control policy shows that whites have substantially harsher attitudes concerning punishment and greater confidence in the justice system and its practitioners than do blacks (e.g., Unnever, Cullen, and Lero-Jonson, in this volume). Lawrence Bobo and Devon Johnson, concluding an extensive analysis of black/white differences in attitudes toward capital punishment and laws punishing crack cocaine traffickers (mostly black) much more harshly than powder cocaine traffickers (mostly white), observe that

The most consistent predictor of criminal justice policy attitudes 
is, in fact, a form of racial prejudice. While white racial resentment does not ever explain a large share of the variation in any of the attitudes we have measured, it is the most consistently influential of the variables outside of race classification itself. This pattern has at least two implications. It further buttresses the concern that some of the major elements of public support for punitive criminal justice policies are heavily tinged with racial animus and thus quite likely to be resistant to change based on suasion and informationbased appeals. What is more, this pattern reinforces the claim . . . that one major function of the criminal justice system is the regulation and control of marginalized social groups such as African Americans. (2004, pp. 171-72)

There are no easy paths out of the racial dead end in which American crime policy finds itself. The damage has been done to living black Americans: lives have been blighted, life chances have been reduced, and communities have been undermined. Even radical changes in American crime policies can change none of that.

\section{How Can We Do Better?}

Nonetheless, things can be done. One approach, radical decarceration, is corrective. Three others, elimination of bias and stereotyping, abandonment of policies and laws that do unnecessary damage, and creation of devices making their later replication of such policies and laws less likely, are preventative.

\section{A. Radical Decarceration}

Efforts to eliminate bias and stereotyping in official decision making are being made throughout the United States and should continue to be made. Unfortunately, such efforts, even if completely successful, can have only modest effects. The primary drivers of racial disparities are drug and sentencing policies. Table 5 illustrates why elimination of bias and disparities will not significantly lessen the damage racial disparities do. The top row shows black and white imprisonment rates in 2006. ${ }^{17}$ The second row shows what would happen if black rates were decreased by 10 percent, which is a high estimate of the degree to which

\footnotetext{
${ }^{17}$ The black/white ratio is not higher than $5.5: 1$ because the table uses BJS data that exclude Hispanics of either race and because it contains combined data on men and women. The disparity ratio for women in $2006(3.8: 1)$ was significantly lower than that for men (6.3:1) (Sabol, Minton, and Harrison 2007, table 14).
} 
TABLE 5

Disparity in Incarceration Rates, by Race

\begin{tabular}{lccc}
\hline & Black & White & Ratio \\
\hline & & A. Disparity Reduced $10 \%$ & \\
Imprisonment rate, 2006 & 2,661 & 483 & $5.5: 1$ \\
10\% less disparity & 2,395 & 483 & $5.0: 1$ \\
Reduction in prison per 100,000 & 266 & 0 & \\
\cline { 2 - 4 } & \multicolumn{2}{c}{ B. Use of Imprisonment Halved } \\
\cline { 2 - 4 } Imprisonment rate, 2006 & 2,661 & 483 & $5.5: 1$ \\
Imprisonment halved & 1,330 & 241 & $5.5: 1$ \\
Reduction in prison per 100,000 & 1,330 & 241 & \\
\cline { 2 - 4 } & \multicolumn{2}{c}{ C. Return to 1980 Imprisonment Rates } \\
\cline { 2 - 4 } Imprisonment rate, 1980 & 827 & 134 & $6.2: 1$ \\
Reduction in prison per 100,000 & 1,834 & 349 & \\
\hline
\end{tabular}

SOURCE.-Office of Applied Studies, National Survey on Drug Use and Health, various years.

bias and stereotyping enhance disparities, while white rates were left unchanged. The black imprisonment rate would fall from approximately 2,661 per 100,000 to 2,395 and the ratio of black-to-white imprisonment rates would fall from $5.5: 1$ to $5.0: 1$.

If instead, as the fifth row shows, the prison population were cut by half across the board, the ratio of imprisonment rates would remain the same but the black imprisonment rate would fall from 2,661 to 1,330 . Or if, as the penultimate row shows, imprisonment rates were cut to 1980 levels, the black imprisonment rate would be 827 per 100,000 .

The differing implications of these different approaches are enormous. The U.S. Census estimates that 38.34 million U.S. residents in 2006 were black. If the imprisonment rate were halved, the black rate would fall from 26,613 per million to 13,306 . That means that over 500,000 fewer black Americans would be in prison or jail. Returning to the 1980s imprisonment rate would mean 702,400 fewer black Americans behind bars. By contrast, eliminating all effects of bias and stereotyping would free at most 101,900 black Americans.

Of course, every effort should be made to eliminate bias and stereotyping. Their diminution will reduce racial disparities and the absolute size of the bite prisons take out of the black population. In absolute terms, though, that will only nibble at the problem. Only radical de- 
carceration can make a big difference. To attempt to limit damage done to people now entangled in the arms of the criminal justice system, devices need to be created for reducing the lengths of current prison sentences and releasing hundreds of thousands of people from prison. New systems of parole, pardon, and commutation will need to be developed, as well as programs of social welfare and support to ease peoples' transitions back into the free community.

\section{B. Abandonment of Disparity-Causing Policies}

To limit damage to disadvantaged young people not yet ensnared, legislatures will need to repeal laws authorizing capital punishment and creating mandatory minimum sentences, sentences of life without the possibility of parole, and truth-in-sentencing laws. Most such laws were adopted primarily for symbolic or expressive purposes rather than with any basis for believing that they would significantly affect crime rates and patterns, and they do great and disproportionate harm to black Americans.

American jurisdictions will need to establish principled new systems of sentencing guidelines coupled with mechanisms for shortening unduly, disparately, or disproportionately long prison sentences. New guidelines will need to call for proportionate sentences for most crimes measured mostly in weeks and months, as in most other Western countries, and in years only for the most serious crimes.

These may seem millenarian proposals. They are not. They would do little more than return American crime control and punishment policies to the mainstream of Western developed countries. Every other Western country manages to get by without capital punishment, life without the possibility of parole, and prison sentences measured primarily in years and decades.

Alfred Blumstein (1993) years ago showed that American practitioners and policy makers can respond quickly to racial disparity problems. He observed that from 1965 to 1969 , white and nonwhite arrest rates for young offenders were indistinguishable; that from 1970 to 1980 white rates exceeded nonwhite rates; and that thereafter by 1989 nonwhite rates nearly tripled and white rates halved, leaving nonwhite rates nearly four times higher. Figure 13 tells the story. Here is what Blumstein surmises happened:

The decline [in white arrest rates] after the 1974 peak was undoubtedly a consequence of the general trend toward decriminali- 


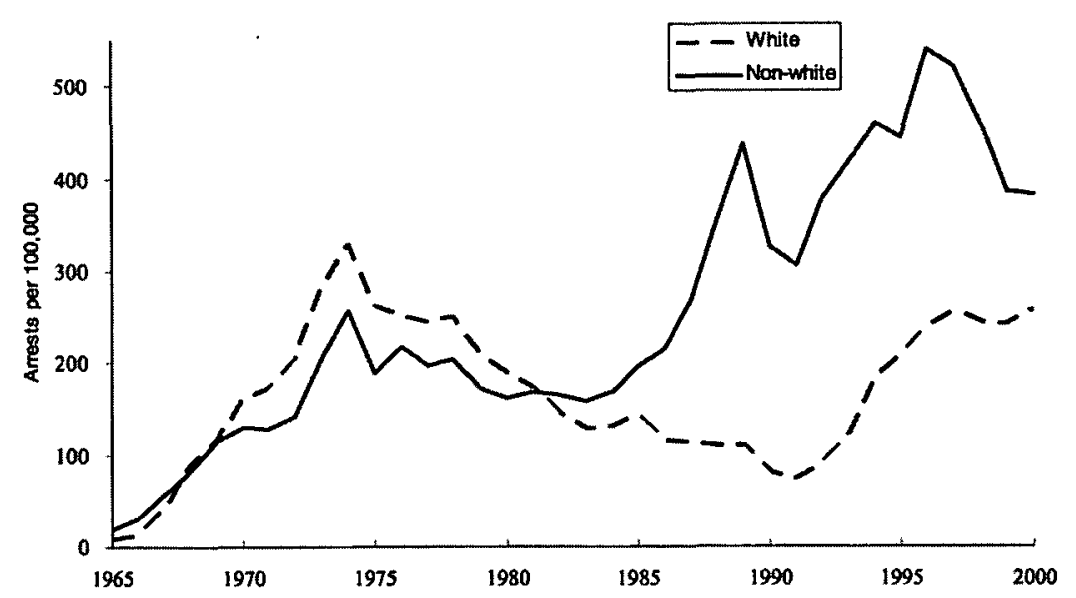

FIG. 13.-Juvenile arrest rate for drug offenses, by race, 1965-2000. Sources: Blumstein (1993); Blumstein and Wallman (2006).

zation of marijuana in the United States. A major factor contributing to that decriminalization was probably a realization that the arrestees were much too often the children of individuals, usually white, in positions of power and influence. These parents certainly did not want the consequences of a drug arrest to be visited on their children, and so they used their leverage to achieve a significant degree of decriminalization. Following the peak, arrest rates for both racial groups declined, and continued to decline for whites. On the other hand, for non-whites, the decline leveled out in the early 1980s and then began to accelerate at a rate of between twenty and twenty-five percent per year, until the peak in 1989. This clearly reflects the fact that drug enforcement is a result of policy choices. (P. 758)

It is not completely cynical to wonder why soaring arrest rates for nonwhite kids in the 1980s did not provoke the kinds of reactions that Blumstein attributes to soaring arrest rates of white kids in the 1970s, and a comparable policy adjustment. Racially differentiated effects of American drug and sentencing policies have been starkly evident for a quarter century.

\section{Race and Ethnicity Impact Statements}

American governments have long used prophylactic measures to guard against unwanted effects of governmental decisions. To protect 
the public purse, legislatures in many states require that legislative proposals be accompanied by or trigger fiscal impact statements. Federal and state laws routinely require the preparation of environmental impact statements before building and other permits may be issued. It is a small step to require that proposals for policy and statutory changes relating to drug and crime control policies carry with them or trigger race and ethnicity impact statements. Projected new laws or policies likely disproportionately to affect members of minority groups adversely should be made subject to strong presumptions against their adoption.

If racially disparate effects of public policies are a problem, and in most policy realms that proposition is self-evident, policy makers in this realm also should be required to declare and justify disparate effects. The second edition of the Model Penal Code (American Law Institute 2007) provides that such statements be required, and a literature on the subject is beginning to develop (Tonry 2004, pp. 221-26; Mauer 2007).

\section{Are Meaningful Changes Possible?}

We realize that our proposals for radical reduction in America's prison population, repeal of repressive legislation, and requirement of race and ethnicity impact statements may strike some readers as fanciful. If racial disparities and the damage they have unarguably done to millions of individual black Americans and their families, and to black Americans as a group, are pressing social problems, then radical measures are called for.

There are pessimistic and optimistic ways to contemplate the future. The pessimistic one is to recall Loïc Wacquant's functionalist analysis of racial hierarchy in American history and the succession of mechanisms by which white domination has been maintained. If slavery was succeeded by Jim Crow, which was succeeded by the racially segregated northern ghettoes, which was succeeded by mass imprisonment, it is hard not to wonder what will substitute for mass imprisonment, or whether mass imprisonment will endure for the reasons Wacquant sketched.

The optimistic one focuses on the good things the civil rights movement accomplished. Sixty years ago, nearly all black Americans were second-class citizens; nearly all were victims of discriminatory practices, norms, and laws. That is no longer true. Today it is primarily 
disadvantaged black Americans who suffer, seemingly for the accident of their births. Perhaps as the normative developments that underlay the civil rights movement wrestle with the functionalist developments that Wacquant described, a time will come when our proposals do not look fanciful. They are simple proposals that aim to redress profound social injustices. Seen that way, they are not radical at all.

\section{REFERENCES}

American Friends Service Committee. 1971. Struggle for Fustice. New York: Hill and Wang.

American Law Institute. 2007. Model Penal Code: Sentencing. 2nd ed. Tentative draft no. 1 (April 9). Philadelphia: American Law Institute.

Baldus, David C., George G. Woodworth, and Charles A. Pulaski Jr. 1990. Equal fustice and the Death Penalty: A Legal and Empirical Analysis. Boston: Northeastern University Press.

BJS (Bureau of Justice Statistics). 1984. "The 1983 Jail Census." Washington, DC: U.S. Department of Justice, Bureau of Justice Statistics.

__ 1990. "Profile of Jail inmates 1978." Washington, DC: U.S. Department of Justice, Bureau of Justice Statistics.

- 2006. "Prisoners in 2004." Washington, DC: U.S. Department of Justice, Bureau of Justice Statistics.

. 2007. "Prison and Jail Inmates at Midyear 2006." Washington, DC: U.S. Department of Justice, Bureau of Justice Statistics.

Blair, Irene V., Kristine M. Chapleau, and Charles M. Judd. 2005. "The Use of Afrocentric Features as Cues for Judgment in the Presence of Diagnostic Information." European Fournal of Social Psycbology 35:59-68.

Blair, Irene V., Charles M. Judd, and Kristine M. Chapleau. 2004. "The Influence of Afrocentric Facial Features in Criminal Sentencing." Psycbological Science 15(10):674-79.

Blair, Irene V., Charles M. Judd, and Jennifer L. Fallman. 2004. "The Automaticity of Race and Afrocentric Facial Features in Social Judgments." Fournal of Personality and Social Psychology 87(6):763-78.

Blair, Irene V., Charles M. Judd, Melody S. Sadler, and Christopher Jenkins. 2002. "The Role of Afrocentric Features in Person Perception: Judging by Features and Categories." Fournal of Personality and Social Psychology 83(1): $5-25$.

Blank, Rebecca M., Marilyn Dabaddy, and Constance F. Citro, eds. 2004. Measuring Racial Discrimination. Washington, DC: National Academy Press.

Blasi, Gary, and John T. Jost. 2006. "System Justification Theory and Research: Implications for Law, Legal Advocacy, and Social Justice." California Law Review 94:1119-68. 
Blumstein, Alfred. 1982. "On Racial Disproportionality of the United States" Prison Populations." Fournal of Criminal Law and Criminology 73:1259-81.

- . 1993. "Racial Disproportionality of U.S. Prison Populations Revisited." University of Colorado Law Review 64:743-60.

Blumstein, Alfred, and Allen Beck. 1999. "Population Growth in U.S. Prisons, 1980-1996." In Prisons, edited by Michael Tonry and Joan Petersilia. Vol. 26 of Crime and fustice: A Review of Research, edited by Michael Tonry. Chicago: University of Chicago Press.

Blumstein, Alfred, Jacqueline Cohen, Susan Martin, and Michael Tonry, eds. 1983. Research on Sentencing: The Search for Reform. Washington, DC: National Academy Press.

Blumstein, Alfred, and Joel Wallman. 2006. "The Crime Drop and Beyond." Annual Review of Laws and Social Sciences 2:125-46.

Bobo, Lawrence, and Devon Johnson. 2004. "A Taste for Punishment: Black and White Americans' Views on the Death Penalty and the War on Drugs." Du Bois Review 1:151-80

Bonczar, Thomas P. 2003. "Prevalence of Imprisonment in the U.S. Population, 1974-2001." Washington, DC: U.S. Department of Justice, Bureau of Justice Statistics.

Cahalan, Margaret W. 1986. Historical Correction Statistics in the United States, 1850-1984. Washington, DC: U.S. Department of Justice, Bureau of Justice Statistics.

Chen, Emmeline S., and Tom R. Tyler. 2002. "Cloaking Power: Legitimizing Myths and the Psychology of the Advantaged." In The Use and Abuse of Power: Multiple Perspectives on the Causes of Corruption, edited by Annette Y. Lee-Chai and John A. Bargh. New York: Psychology Press, Taylor and Francis.

Clear, Todd. 2007. Imprisoning Communities: How Mass Incarceration Makes Disadvantaged Neighborboods Worse. New York: Oxford University Press.

-. In this volume. "Communities with High Incarceration Rates."

Dills, Angela K., Jeffrey A. Miron, and Garrett Summers. 2008. "What Do Economists Know about Crime?" Working Paper no. 13759. Cambridge, MA: National Bureau of Economic Research.

Doob, Anthony, and Cheryl Webster. 2003. "Sentence Severity and Crime: Accepting the Null Hypothesis." In Crime and fustice: A Review of Research, vol. 30, edited by Michael Tonry. Chicago: University of Chicago Press.

Du Bois, W. E. B. 1988. "The Negro Criminal." In The Economics of Race and Crime, edited by Samuel L. Myers and Margaret C. Simms. New Brunswick, NJ: Transaction Books. (Originally published 1899.)

Eberhardt, Jennifer L., Paul G. Davies, Valerie J. Purdie-Vaughns, and Sheri Lynn Johnson. 2006. "Looking Deathworthy: Perceived Stereotypicality of Black Defendants Predicts Capital-Sentencing Outcomes." Psychological Science 17(5):383-86.

Eberhardt, Jennifer L., Phillip Atiba Goff, Valerie J. Purdie, and Paul G. Davies. 2004. "Seeing Black: Race, Crime and Visual Processing." Fournal of Personality and Social Psycbology 87(6):876-93. 
Engel, Robin Shepard, and Jennifer M. Calnon. 2004. "Examining the Influence of Drivers' Characteristics during Traffic Stops with Police: Results from a National Survey." Fustice Quarterly 21(1):49-90.

Fagan, Jeffrey, and Richard B. Freeman. 1999. "Crime and Work." In Crime and Fustice: A Review of Research, vol. 25, edited by Michael Tonry. Chicago: University of Chicago Press.

Federal Bureau of Investigation. 2005. Crime in the United States, 2004. Washington, DC: U.S. Department of Justice.

Gest, Ted. 2001. Crime and Politics: Big Government's Erratic Campaign for Law and Order. New York: Oxford University Press.

Gilliard, Darrell K., and Allen J. Beck. 1996. Prison and Jail Inmates, 1995. Washington, DC: U.S. Department of Justice, Bureau of Justice Statistics.

Greenwald, Anthony, and Linda Hamilton Krieger. 2006. "Implicit Bias: Scientific Foundations." California Law Review 94:945-67.

Harrington, Michael P., and Cassia Spohn. 2007. "Defining Sentence Type: Further Evidence against Use of the Total Incarceration Variable." Journal of Research in Crime and Delinquency 44(1):36-63.

Hofstadter, Richard. 1965. The Paranoid Style in American Politics and Otber Essays. Chicago: University of Chicago Press.

Jones, Trina. 2000. "Shades of Brown: The Law of Skin Color." Duke Law fournal 49:1487-1557.

Langan, Patrick. 1985. "Racism on Trial: New Evidence to Explain the Racial Composition of Prisons in the United States." Journal of Criminal Law and Criminology 76:666-83.

Lieberson, Stanley. 1980. A Piece of the Pie-Blacks and White Immigrants since 1980. Berkeley and Los Angeles: University of California Press.

Liptak, Adam. 2007. "Whittling Away, but Leaving a Gap." New York Times (November 17), p. A21.

Loury, Glenn C. 2002. The Anatomy of Racial Inequality. Cambridge, MA: Harvard University Press.

- 2007. "Racial Stigma, Mass Incarceration and American Values." Tanner Lectures in Human Values delivered at Stanford University, April 4 and 5. http://www.econ.brown.edu/fac/Glenn_Loury/louryhomepage/.

MacCoun, Robert, and Karin D. Martin. Forthcoming. "Drug Abuse." In Handbook on Crime and Punishment, edited by Michael Tonry. New York: Oxford University Press.

Maddox, Keith B., and Stephanie A. Gray. 2002. "Cognitive Representations of Black Americans: Reexploring the Role of Skin Tone." Personality and Social Psychology Bulletin 28:250-59.

Massey, Douglas S. 2007. Categorically Unequal. New York: Russell Sage Foundation.

Massey, Douglas S., and Nancy Denton. 1993. American Apartheid: Segregation and the Making of the Underclass. Cambridge, MA: Harvard University Press.

Mauer, Marc. 2007. "Racial Impact Statements as a Means of Reducing Unwarranted Sentencing Disparities." Obio State Fournal of Criminal Law 5: 19-46. 
McDonald, Douglas C., and Kenneth C. Carlson. 1993. Sentencing in the Federal Courts: Does Race Matter? Washington DC: U.S. Department of Justice, Bureau of Justice Statistics.

Moynihan, Daniel Patrick. 1965. The Negro Family: The Case for National Action. Washington, DC: U.S. Department of Labor, Office of Policy Planning and Research.

Murray, Joseph, and David P. Farrington. In this volume. "Effects of Parental Imprisonment in Children."

Myrdal, Gunnar. 1944. An American Dilemma-the Negro Problem and Modern Democracy. New York: Harper and Row.

Pizzi, William T., Irene V. Blair, and Charles M. Judd. 2005. "Discrimination in Sentencing on the Basis of Afrocentric Features." Michigan foumal of Race and Law 10:327-53.

Provine, Doris Marie. 2007. Unequal under Law: Race in the War on Drugs. Chicago: University of Chicago Press.

Raphael, Steven, Harry Holzer, and Michael Stoll. 2006. "How Do Crime and Incarceration Affect the Employment Prospects of Less Educated Black Men?" In Black Males Left Bebind, edited by Ronald Mincy. Washington, DC: Urban Institute.

Sabol, William J., Todd D. Minton, and Paige M. Harrison. 2007. "Prison and Jail Inmates at Midyear 2006." Washington, DC: U.S. Department of Justice, Bureau of Justice Statistics.

Shane-Dubow, Sandra, Alice P. Brown, and Erik P. Olsen. 1985. Sentencing Reform in the United States: History, Content and Effect. Washington, DC: U.S. Government Printing Office.

Snell, Tracy L. 2007. "Capital Punishment, 2006." Washington, DC: U.S. Department of Justice, Bureau of Justice Statistics.

Spohn, Cassia. 2000. "Thirty Years of Sentencing Reform: The Quest for a Racially Neutral Sentencing Process." In Criminal 7ustice 2000, vol. 3, edited by the U.S. National Institute of Justice. Washington, DC: U.S. Department of Justice, National Institute of Justice.

- 2002. How Do Judges Decide? The Search for Fairness and Justice in Punisbment. Thousand Oaks, CA: Sage.

Tonry, Michael. 1995. Malign Neglect: Race, Crime, and Punishment in America. New York: Oxford University Press.

-1996. Sentencing Matters. New York: Oxford University Press. 2004. Thinking about Crime: Sense and Sensibility in American Penal Culture. New York: Oxford University Press.

- 2005. "Obsolescence and Immanence in Penal Theory and Policy." Columbia Law Review 105:1233-75.

2008. "Crime and Human Rights-How Political Paranoia, Religious

Fundamentalism, and Constitutional Obsolescence Combined to Devastate Black America." Criminology 46(1):1-34.

- In this volume. "Learning from the Limits of Deterrence Research."

Unnever, James D., Francis T. Cullen, and Cheryl N. Lero-Jonson. In this volume. "Race, Racism, and Support for Capital Punishment." 
U.S. Department of Commerce. 2006. Statistical Abstract of the United States: 2007. Washington, DC: U.S. Government Printing Office.

U.S. Sentencing Commission. 1995. 1995 Special Report to the Congress: Cocaine and Federal Sentencing Policy. Washington, DC: U.S. Sentencing Commission.

- 2007. Cocaine and Federal Sentencing Policy. Washington, DC: U.S. Sentencing Commission.

Wacquant, Loïc. 2002a. "Deadly Symbiosis: Rethinking Race and Imprisonment in Twenty-first-Century America." Boston Review (April/May).

- 2002b. "From Slavery to Mass Incarceration." New Left Review 13(January-February):41-60.

Walker, Samuel, Cassia Spohn, and Miriam DeLone. 2006. The Color of fustice: Race, Etbnicity, and Crime in America. 4th ed. Belmont, CA: Wadsworth.

Walmsley, Roy. 2007. World Prison Population List. 7th ed. London: International Centre for Prison Studies.

Western, Bruce. 2006. Punisbment and Inequality in America. New York: Russell Sage Foundation.

Wilson, James Q. 1990. "Drugs and Crime." In Drugs and Crime, edited by Michael Tonry and James Q. Wilson. Vol. 13 of Crime and Fustice: A Review of Research, edited by Michael Tonry and Norval Morris. Chicago: University of Chicago Press.

Wilson, William Julius. 1978. The Declining Significance of Race: Blacks and American Institutions. Chicago: University of Chicago Press. 1987. The Truly Disadvantaged: The Inner City, the Underclass, and Public Policy. Chicago: University of Chicago Press. 